This document is the Accepted Manuscript version of a Published Work that appeared in final form in Industrial \& Engineering Chemistry Reseach, copyright (C) American Chemical Society after peer review and technical editing by the publisher.

To access the final edited and published work see https://doi.org/ 10.1021/acs.iecr.9b02567

This Accepted Manuscript version of a Published Work is available from

https://hdl.handle.net/10195/74955

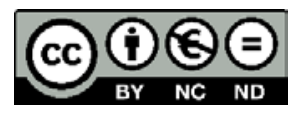

This postprint version is licenced under a Creative Commons Attribution-NonCommercial-NoDerivatives 4.0.International. 


\title{
Curing of air-drying paints: a critical review
}

\author{
Jan Honzíček*
}

Institute of Chemistry and Technology of Macromolecular Materials, Faculty of Chemical Technology, University of Pardubice, Studentská 573, 53210 Pardubice, Czech Republic.

Air-drying paints; autoxidation; alkyd; oriental lacquer; drier.

\begin{abstract}
This review article provides a comprehensive overview of curing processes relevant to air-drying paints. It is focused not only on binders derived from plant oils but also on oriental lacquers and their synthetic congeners as their solidification and hardening processes are driven by chemical reactions with air-oxygen. The main aim of this article is to bring a critical look on this subject omitting deep-seated misinterpretation and oversimplification often appearing in the field of paint technology. Such objective was achieved by utilization of the latest knowledge appearing in various areas of chemical research, e.g. organic chemistry, biochemistry, physical chemistry, computational chemistry and inorganic chemistry.
\end{abstract}

\section{Introduction}

The binders cured by action of air-oxygen have been established as a significant group of paints used in protective and decorative coatings. In recent years, they have become very popular since a large part of the raw materials is available from biologically renewable feedstocks. ${ }^{2}$ Modern airdrying paints, including high-solid (HS) and water-borne (WB) formulations, also fulfill ecological concerns about low emission of volatile organic compounds (VOC) ${ }^{3,4}$ and total life cycle. ${ }^{2}$

Air-drying process, during which a liquid paint layer converts to the durable film, is commonly known as autoxidation. It usually proceeds on unsaturated hydrocarbon tails originating in fatty acid esters of plant oils. 5 In case of traditional oriental lacquers and related binders, the autoxidation of lipid tails is preceded by enzymatically catalyzed oxidative polymerization of catechol moieties. ${ }^{6-8}$ Curing by action of air-oxygen is also evidenced on some purely synthetic binders 9,10 and reactive diluents used in paint industry. ${ }^{1,12}$

The autoxidation is generally a very slow process. In practice, it has to be catalyzed by transition metal compounds known as "primary driers" or enforced by elevated temperature. Currently used cobalt(II) carboxylates are very powerful primary driers and widespread in field airdrying paints intended for industrial as well as do-it-yourself market. Their main disadvantages involve decreasing activity in WB formulations upon standing ${ }^{13}$ and poor through-drying of HS binders. ${ }^{14}$ Furthermore, they are under deep toxicological scrutiny by Cobalt REACH Consortium of European Chemical Agency as a suspect carcinogens, ${ }^{15,16}$ which stimulates the paint producers in a search for adequate alternatives. It is necessary to pointed out that the concept of a primary drier with negligible biological impact is a very ambitious goal since lipid autoxidation commonly proceeds in living organisms and any primary drier must affect it in some extent. Of course, the cobaltreplacement is a very beneficial trend for human health but the nature of primary driers inevitably leads to increased oxidative stress in human organism, which may lead to various diseases. ${ }^{17}$

Although the quest for cobalt replacement is ongoing for about two decades..$^{18}$ only few cobalt-free driers are commercially available and each them replaces cobalt compounds only partially owing to a very specific catalytic behavior of cobalt(II) carboxylates. Furthermore, the replacement is not a simple process as the paint additives (e.g. secondary driers and antiskinning agents) are well tried only in combination with cobalt compounds and introduction of another primary driers leads to expansive and time-consuming tuning of new paint formulations. The field cobaltfree driers faces particular challenges mainly in field of ecologically sustainable HS and WB formulation. In both fields, a quest for driers with properties superior to currently used cobalt(II) carboxylates is still ongoing. The HS binders place strong emphasis on performance of the drier due to negligible effect of physical drying as the film for- 
mation proceeds solely chemically. ${ }^{4}$ In case of WB formulations, the drier have to be enough hydrolytically stable and sufficiently miscible with alkyd phase. ${ }^{2}$

Table 1. Contents (\%) of unsaturated fatty acids in the seed oils. The column headings " $m: n$ " signify: $m=$ number of carbon atoms, $n=$ number of non-conjugated double bonds.

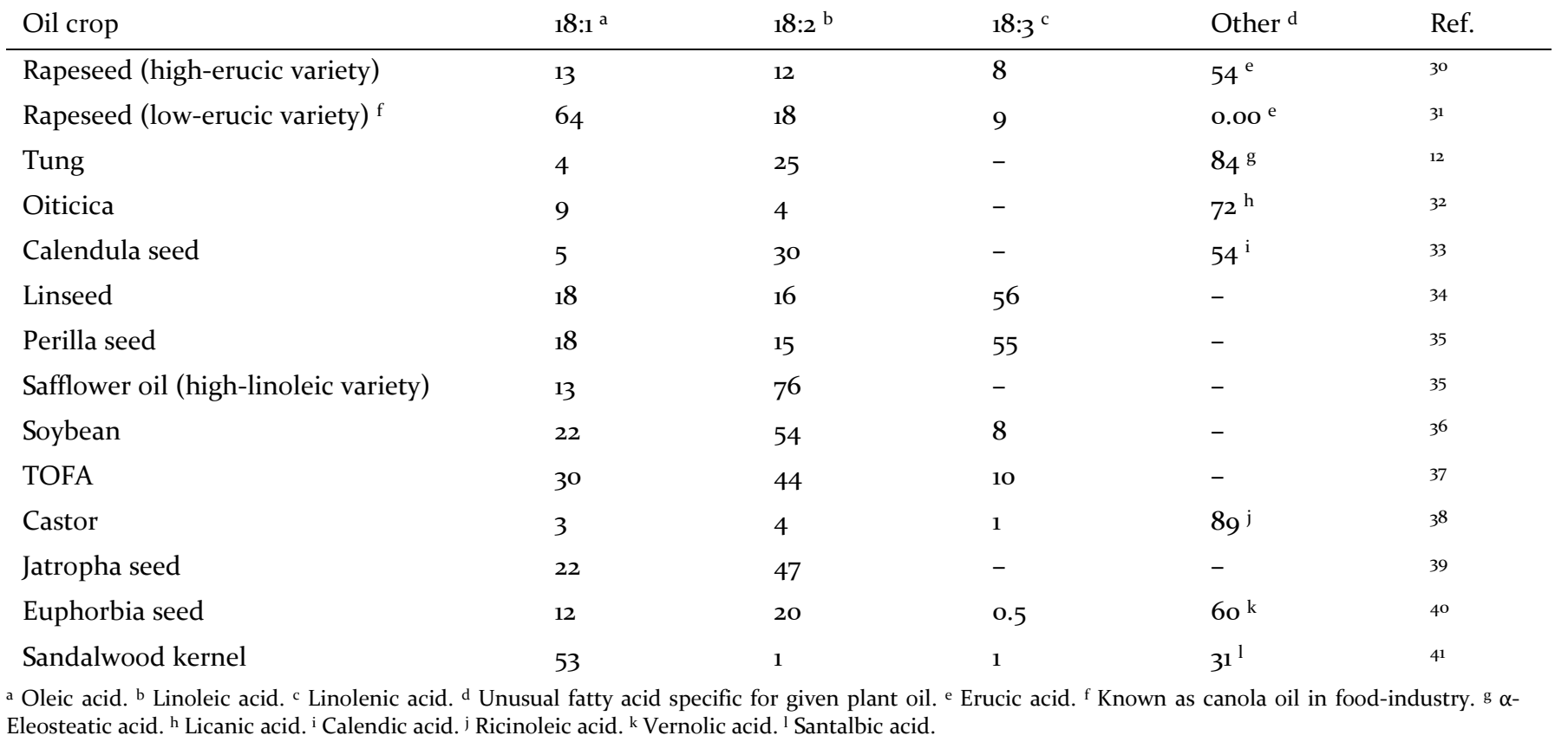

For targeted design of highly active driers, a detailed knowledge of the autoxidation process is very necessary. Since several authors already provide a detailed overview of lipid autoxidation ${ }^{19-21}$ and paint additives, ${ }^{22-24}$ our goal is to bring a critical view on mechanism of autoxidation process relevant to paint technology covering clarification the role of cobalt-based driers and recent developments in field of cobalt replacement.

\section{Plant oils}

Oils, extracted from plants, have been used for decorative purposes and wood protection since time immemorial. Domesticated form of flax (Linum usitatissimum), which is an important source of drying oil, appears in early Neolithic Age sites in Syria and Greek dating back to 6000 B.C. ${ }^{25}$ Oil seeds of safflower (Carthamus tinctorius) were evidences in early Bronze Age (300o B.C.) sites in Syria and then spread to Egypt, the Aegean and south-eastern Europe. ${ }^{26}$

Refined plant oils consist mainly of fatty acid triglycerides, which composition is somewhat characteristic for given species (Table 1) but fatty acid pattern may vary widely in different oil crops due to specific climatic conditions, different extraction process, another species variety or other factors. For example, rape (Brassica napus) breeding enabled to reduce selectively content of erucic acid in rapeseed oil (aka canola oil), which serves demands of food industry (Table 1). ${ }^{27}$ Other examples, demonstrating how fatty acid pattern can be changed, is given by new safflower and sunflower (Helianthus annuus) varieties producing seeds with high contents of oleic acid. ${ }^{28,29}$

Reactivity of refined oils is given by fatty acid pattern; mainly by degree of unsaturation, position of double bonds and presence of other function groups in the fatty acid chains. Drying properties are approached by iodine value (IV) ${ }^{42}$ which corresponds to degree of unsaturation and enables to divide them arbitrarily to following classes: nondrying (IV < 125), semi-drying (IV = 125-140) and drying (IV $>$ 140). 43 The industrially important plant oils contain a mixture of unsaturated fatty acid esters, usually $C_{18}$ (Table 1). Larger quantities of saturated fatty acid esters occur in coconut oil (Cocos nucifera), palm oil (Elaeis guineensis and $E$. oleifera) and palm kernel oil. ${ }^{28,35}$

Rapid air-drying is observed for oils with a large content of fatty acids with conjugated double bonds such as $\alpha$-eleostearic, licanic and calendic acid (Scheme 1). Among them, tung oil (aka Chinese wood oil) is especially commercially valuable due to about $84 \%$ content of $\alpha$-eleostearic acid,,$^{12}$ which provides coatings of excellent durability and chemical resistance. It is used as a chief component of oil paints and HS binders for waterproof lacquers. ${ }^{44}$ Alkyl esters derived from tung oil were reported as reactive diluents. ${ }^{12}$ Tung oil is extracted from nutlike seeds of trees Aleurites fordii and A. montana. Relative tree A. cordata gives tung oil of very similar properties that is sometimes called Japanese wood oil. 45 Trees of the genus Aleurites are native in Asia but there is little known about early history of tung oil. Very early note is by Marco Polo, who refers 
that Chinese ships were calked and impregnated by some kind of tung oil instead of using pitch as usual in Europe. ${ }^{46}$ In western countries, its superior properties were recognized at beginning of $2 \mathrm{O}^{\text {th }}$ century, which led to cultivation of $A$. fordii in subtropical and tropical areas of the world. After discontinued tung oil production in United States, major growing areas include China, Argentina, Paraguay and parts of Africa. ${ }^{47}$

Minor production of conjugated fatty acid esters is covered by oiticica oil, which is extracted from seeds of Licania rigida grown in Brazil. Such oil, containing about $72 \%$ of licanic acid, is commonly used as an alternative or supplement of tung oil.32,43 I could be noted that keto group of licanic acid is not utilized for modification of paint binders mainly owing to high reactivity of the conjugated double bond system.

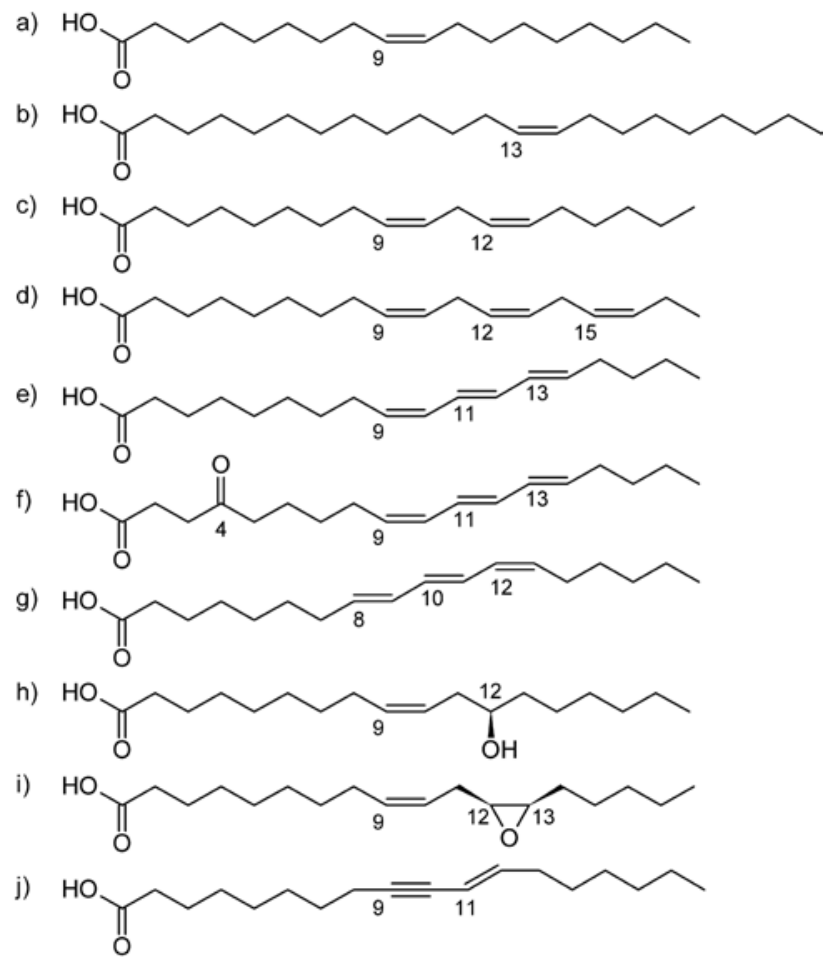

Scheme 1. Fatty acids of plant seed oils relevant to air-drying paints: a) oleic acid, b) erucic acid, c) linoleic acid, d) linolenic acid, e) eleostearic acid, f) licanic acid, g) calendic acid, h) ricinoleic acid, i) vernolic acid, j) santalbic acid.

Conjugated fatty triglycerides are also found in seeds of other plants such as bitter gourd (Momordica charantia), pomegranate (Punica granatum), snakegourd (Trichosanthes kirilowii), catalpa (Catalpa bignonoides and $C$. ovata) and jacaranda (Jacaranda mimosifiola).48 Nevertheless, only pot marigold (Calendula officinalis) is currently under agronomic research, ${ }^{49}$ which could result in sustainable oil production and application in paint-producing industry. ${ }^{12}$ The latest varieties of marigold give a seed oil containing about $55 \%$ of calendic acid (Scheme 1 ).

Fatty acids triglycerides with non-conjugated double bonds are commonly found in many plant oils and appear almost exclusively in low reactive cis-configuration. They differ considerably in their oxidative stability depending on number of double bonds in the fatty acid tail. Esters of mono-unsaturated fatty acids are oxidative stable at room temperature due to absence of activated methylene groups surrounded by two double bonds. Such bis-allylic moiety, present in linoleic and linolenic acids (Scheme 1), is responsible for curing in majority of air-drying paints, which mechanism will be discussed in detail bellow.

Linseed oil, obtained from flax seeds (Linum usitatissimum), was used as a chief ingredient of varnishes for many centuries due to high content of linolenic acid. Refined oil is usually used in combination with primary driers providing sufficient drying time. Physical-chemical properties of linseed oil can be improved by various modifications. ${ }^{44,50}$ So-called "boiled oil" is obtained when oil is heated on air in presence of drier. Such processing results in increased viscosity. It improves leveling, reduces risk of flow and shortens drying times. "Blown oil" is produced in similar manner but the autoxidation proceeds in absence of metal drier. The product is typically of higher viscosity but the drying time stays relatively long..$^{50,51}$ The linseed oil can be modified at elevated temperature under inert atmosphere or under vacuum. The appearing "stand oil" gives paint films with increased hardness, better gloss and lighter coloration than aforementioned boiled or blown oils. ${ }^{44}$ Due to absence of air-oxygen, the oil does not undergo usual autoxidation but some kind of polymerization process, which mechanism has not been fully recognized. Although concept of conjugation/Diels-Alder cyclization was widely accepted,52,53 there are many doubts about it.54 In recent work, Doll et al. outlined more likely radical pathway, which insists further experimental and theoretical evidence to be approved. 55 In second half of $20^{\text {th }}$ century, modified oils were almost fully replaced by alkyd formulations due to lower price and better performance. Until now, linseed oil is used as a binder for do-it-yourself varnishes for wood protection and for production of artistic oil paints. The main drawback of linseed oil films is yellow appearance and tendency to yellow when stored in dark (so-called "dark-yellowing"). ${ }^{6}$ This effect is reduced considerably in oils with low content of linolenic acid such as seed oil derived from common varieties of safflower ( $\mathrm{Car}$ thamus tinctorius). Due to high content of linoleic acid, safflower oil is a very suitable binder for white and palepigmented artistic paints. ${ }^{57}$ Oil-based paints are also accessible from seeds of perilla (Perilla frutescens) since their oil has a very similar fatty acid pattern to linseed oil (Table 1). $5^{8}$

Semi-drying oils are extensively used for production of synthetic air-drying binders such as alkyd resins and airdrying epoxy esters. They form the chief ingredient for production of various solvent-borne (SB) and WB formulations. Demands of paint industry on the semi-drying oil is currently covered mainly by oil extracted from soybeans (Glycine max), due to high content of linoleic acid (Table 1), high yield, extensive production and other economic reasons. Fast-drying synthetic binders are accessible from a distillation fraction of tall oil known as "tall oil fatty acids" (TOFA), which contains $<2 \%$ of rosin acids. The crude tall oil, which name derives from Swedish name for pine, is 
a major byproduct of Kraft pulping. TOFA, unlike seed oils, consists of free fatty acids, which brings several benefits within alkyd resins production. ${ }^{37}$ Another approach giving fast-drying synthetic resins involves the use of aforementioned drying oils or dehydrated castor oil containing conjugated ricinenic acid. $3^{8}$ Castor oil, extracted from Ricinus communis, is readily available non-drying oil containing free hydroxyl group, which is extensively utilized to modification of synthetic resins. 59

There are several oil-bearing plants recognized as a potential feedstock of semi-drying oils or oils with unusual function groups. ${ }^{60,61}$ Among them, Jatropha curcas is the most promising for industrial use as it is adapted to different type of lands including degraded land not competing to food production. Although initial plantation brought rather disappointment, improved agronomic practices can bring valuable linoleic acid-rich oil (Table 1) ${ }^{39,62}$ suitable not only for bio-diesel production ${ }^{63}$ but also for application in paint industry. ${ }^{64}$

In recent years, increasing interest is given to cultivation of Euphorbia lagascae, which seed oil contain a large quantity of epoxy fatty acid known as vernolic acid. $4^{0,65}$ Interesting synthetic application are also supposed for Western Australian sandalwood (Santalum spicatum) kernel oil due to a high content of santalbic acid (aka ximenynic acid). ${ }_{41,61,66}$

\section{Resins modified with fatty acids}

Synthetic air-drying binders are usually based on saturated polyesters modified with fatty acids; known as alkyd resins. They were introduced into market in 1930 and their brief history has been overviewed elsewhere. ${ }^{2}$ Common alkyd resins are produced from dicarboxylic acids, alcohols of higher functionality and plant oils or purified fatty acids using various synthetic protocols. ${ }^{5}$ Idealized structure of alkyd resin consists of a linear polyester backbone decorated with fatty acid tails (Scheme 2 ). In practice, higher functionality of polyalcohol leads to branching but the extensive formation of three-dimensional network has to be avoided as it leads to undesirable gel formation. It should be noted that improved film-forming properties of alkyd resins are not at the cost of partial degradation of fatty acids as in case of aforementioned modified-oils (boiled, blown and stand oils). Due to polymeric character of the synthetic binders, solvent evaporation plays an important role in the film-formation process and allows the extensive use of semidrying oils, as lower density of crosslinking is needed to obtain hard polymeric films than in case of untreated plant oils.

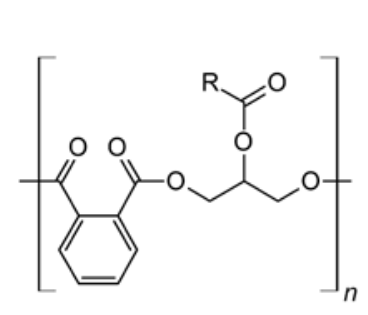

A

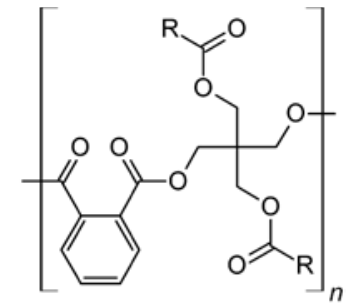

B
Scheme 2. Idealized structures of alkyd resins based on A) phthalic acid/glycerol/fatty acids, B) phthalic acid/pentaerythritol/fatty acids. $\mathrm{R}=$ fatty acid tail.

Alkyd resins are characterized by fatty acid content reported as oil length (OL), which is defined as mass of plant oil incorporated into $100 \mathrm{~g}$ of resin. ${ }^{5}$ The usual classification on resins of short $(\mathrm{OL}<40)$, medium $(\mathrm{OL}=40-60)$ and long oil length $(60<\mathrm{OL}<70)$ is arbitrary and may vary according authors. ${ }^{5}$ Alkyd resin based on phthalic acid/glycerol/ $\mathrm{C}_{18}$-fatty acids can reach OL of 60.5 when considered idealized structure with long linear backbone and all hydroxyl groups esterified (Scheme 2; structure A). Considerably higher value could be obtained for pentaerythritol analogue $(\mathrm{OL} \leq 74.9)$ due to higher functionality of the polyol (Scheme 2; structure B). Alkyd resins of oil length higher than 70, known as alkyd oils, usually consist of oligomeric species (Scheme 3). Due to lower viscosity at given concentration, alkyd oils are often used as the chief component of HS formulations. ${ }^{67}$ It could be noted that lower molecular weight of HS binders declines the role of solvent evaporation in film-formation process, which is usually compensated by use of fast-drying drying oils or reactive diluents.11,12

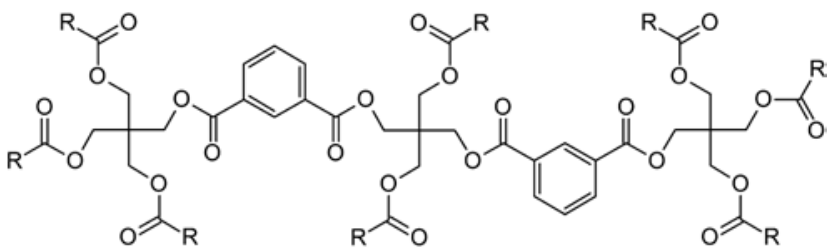

Scheme 3. One of the idealized alkyd oil components, appearing in alkyd resin based on isophthalic acid/pentaerythritol/fatty acids. Properties of the component: $\mathrm{OL}=$ $86 \%, \mathrm{M}_{\mathrm{r}}=2810 \mathrm{~g} / \mathrm{mol} . \mathrm{R}=$ fatty acid tails. ${ }^{67}$

Beside common alkyd binders, based solely on polyesters, a large variety of modified and hybrid binders were introduced into paint market. In hybrid binders, polysiloxane or phenolic resins are grafted on alkyd framework. Attachment of polyamide chains on alkyd resin is utilized for production of thixotropic paints resistant to running and sagging. Alkyd modification could be also done on the fatty acid tails. Industrially important binder are given by copolymerization with styrene (styrenated alkyds) and acrylates (acrylated alkyds). The later modification is suitable for production of a large variety of WB binders (alkyd emulsions). So-called urethanized alkyds are obtained by partial replacement of dibasic acid by polyfunctional isocyanates. ${ }^{5}$

Air-drying epoxy esters is another group of binders modified with plant oils although not belonging to the group of alkyd resins. Their drying is based on autoxidation of fatty acids attached on polymeric epoxide backbone. A simplified structure or air-drying epoxy ester binder is given in Scheme $4 .^{5}$

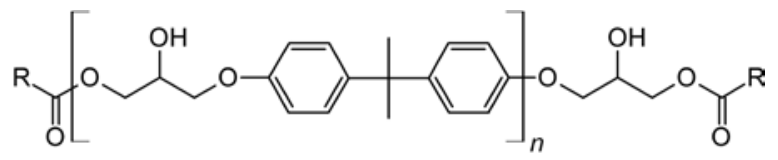


Scheme 4. Idealized structures of epoxy ester resin. $\mathrm{R}=$ fatty acid tail.

\section{Resins based on phenolic lipids}

Phenolic lipids are chief components of traditional oriental lacquers used for decoration and protection of artistic wood, porcelain and metal objects for thousands of years. ${ }^{68}$ There are three kinds of trees used for the oriental lacquer production; namely Toxicodendron vernicifluum, Toxicodendron succedaneum and Gluta usitata. ${ }^{69,70}$ The tree sap, harvested by tapping, is a latex material giving after processing a self-crosslinking resin. Curing of the oriental lacquers is a very slow process and the final films are tough, brilliant and resistant to water, alcohol and oils but sensitive by UV-radiation. ${ }^{71}$

The most highly appreciated lacquer, commonly known as "urushi", originates from Toxicodendron vernicifluum, grown in Japan, China and Korea. ${ }^{6,72}$ Its chief component, responsible for crosslinking, is a phenolic lipid called urushiol. It is a diverse mixture of 3 -substituted catechols bearing predominantly $C_{15}$ unsaturated aliphatic tails. ${ }^{73,74}$ The dense crosslinking of the cured urushi films is mainly due to a high content of $\mathrm{C}_{15}$-triene catechol, shown in Scheme 5 (structure A), which contains both reactive conjugated double bond system and activated methylene group in 10-position (Scheme 5 )..$^{72}$ In Vietnam and Taiwan, phenolic lacquer originating from Toxicodendron succedaneum have been used. The chief component of the resin is called laccol and contains a mixture of catechols having mainly $\mathrm{C}_{17}$ aliphatic side chains in 3-position. Predominate component, containing unsaturated triene moiety, is shown in Scheme 5 (structure B).73 Oriental lacquers from Thailand and Barma are produced from the sap of Gluta usitata. The composition of the chief component, called thitsiol, is more diverse than in the previous cases. It contains not only 3-and 4-catechols bearing linear aliphatic side chains but also derivatives having tails terminated by benzene ring (Scheme 5; structures C).73,75,76

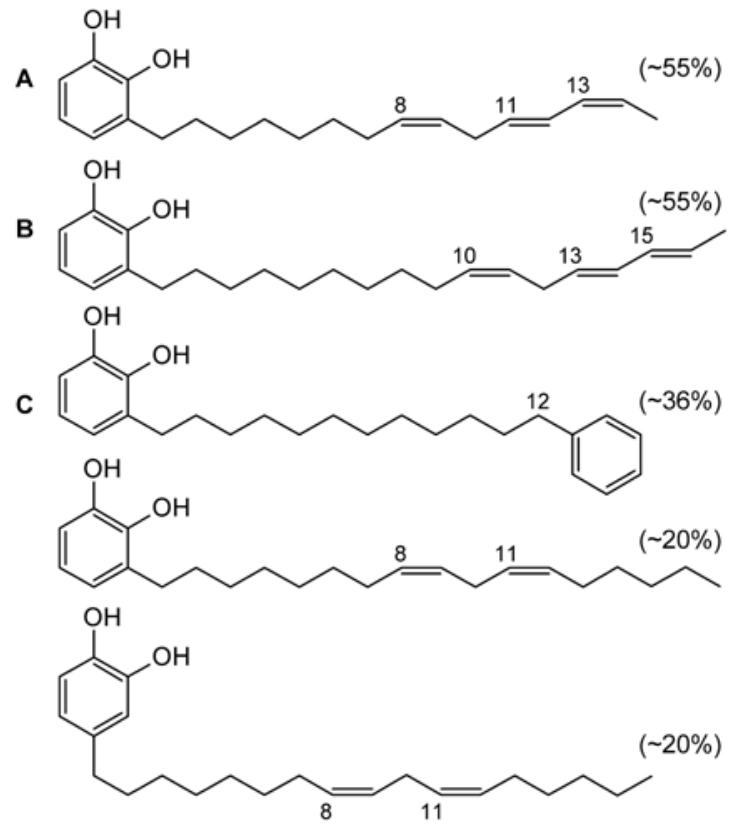

Scheme 5. Structure of the key component of a) urushiol, b) laccol and c) thitsiol with approximate abundance in given phenolic lipid. 73,75

Several convenient synthetic pathways were utilized for preparation of "artificial urushi", which mimics the natural oriental lacquers. Urushiol analogues, used as the lacquer precursors, usually cover cross-linkable polyphenols or naphthols with unsaturated side chains.777,78 The approaches, utilizing cashew nutshell liquid (CNSL), seems to be very promising for paint industry as the raw material is a side product of cashew nut production.7,79-81 The chief component of thermally treated CNSL is cardanol, which is a mixture of phenols having $\mathrm{C}_{15}$ aliphatic chains in 3-position (Scheme 6). ${ }^{82,83}$ CNSL was also used as a key component of several non-classical air-drying binders. ${ }^{84}$

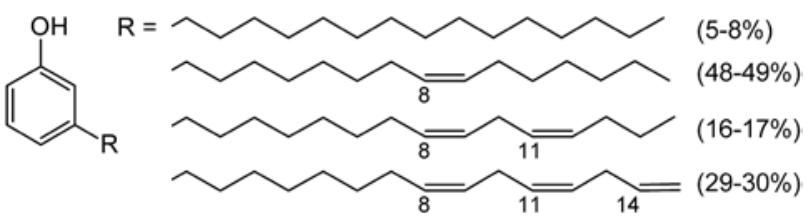

Scheme 6. Main components of thermally treated CNSL. ${ }^{83}$

\section{Miscellaneous binders}

Curing by action of air-oxygen is not limited on natural oils, phenolic lipids and related binders. It is also responsible for curing of several synthetic binders based on liquid polybutadienes ${ }^{9}$ and allyl ether functionalized polyesters. ${ }^{10}$ For these systems, mechanism of the curing process will not be discussed in detail due to limited number of published experiments.

\section{Autoxidation process}

Chemical curing of the oil-based paints is a complex freeradical process including peroxidation, peroxide decomposition and crosslinking reactions. The process is usually called "autoxidation" as it can be considered as autocatalytic and it involves reaction with air-oxygen. The mechanism of autoxidation has been under deep scrutiny for several decades but it is not fully understood due to its complexity and number of side reactions. ${ }^{85}$

\section{Peroxidation}

Initial phase of autoxidation involves peroxidation of the unsaturated hydrocarbons. In last decade, this area exhibits a great development due to extensive research in field of lipid biochemistry. ${ }^{19,20,86}$ Peroxidation process is autocatalytic as produced hydroperoxides can serve as initiators. At ambient temperature, it can proceed on substrates with activated $\mathrm{C}-\mathrm{H}$ bonds such as linoleic or linolenic acid. Alternative, non-radical, pathway involves reaction of unsaturated substrates with singlet oxygen. 


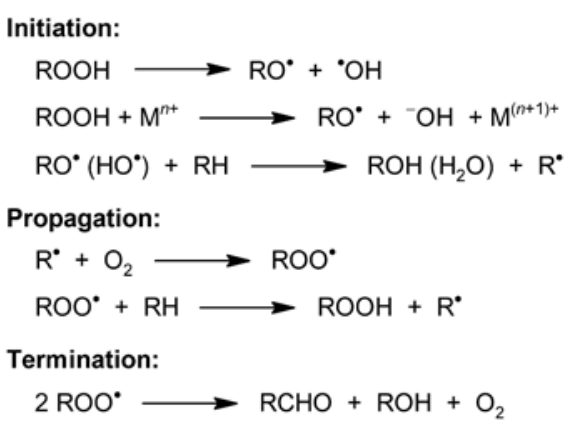

Scheme 7. Peroxidation of hydrocarbons with activated $\mathrm{C}-$ H bond. ${ }^{19,86}$

The radical pathway of lipid peroxidation is initiated by abstraction of hydrogen radical from activated $\mathrm{C}-\mathrm{H}$ bond. The bond could be cleaved through action by heat, UVlight or initiator. ${ }^{87,88}$ Nevertheless, commercial air-drying binders always contain a certain quantity of hydroperoxides, appearing upon synthesis, which decomposition effectively initiates the autoxidation process (Scheme 7). Appearing alkyl radical $\left(\mathrm{R}^{*}\right)$ is highly reactive. It reacts with air-oxygen near the diffusion controlled rate to give peroxyl radical (ROO*). ${ }^{89}$ The key step of propagation involves hydrogen atom transfer from activated $\mathrm{C}-\mathrm{H}$ bond of the lipid tail $(\mathrm{RH})$ to peroxyl radical (ROO'). ${ }^{86,90}$ It should be noted that considerably lower reactivity of ROO', compared with $\mathrm{RO}^{*}$ or $\mathrm{HO}^{*}$, ascertains sufficient selectivity of the peroxidation. ${ }^{19}$ Propagation of the peroxidation process competes with several side reactions (e.g. $\beta$-elimination and radical addition on conjugated double bond system) and with termination producing non-radical products (Scheme 7).91 When substrate is consumed, the autoxidation could be terminated since appeared hydroperoxides are kinetically stable. ${ }^{92}$ Nevertheless, air-drying binders usually undergo peroxide decomposition due to presence of primary driers or harsh reaction conditions.

In case of common air-drying binders, rate of peroxidation process is determined by fatty acid pattern of modifying plant oil. Reactivity of certain fatty acid correlates with strength of activated $\mathrm{C}-\mathrm{H}$ bond as hydrogen atom transfer from fatty acid is a rate-limiting step of the peroxidation. Such correlation is well documented on series of unsaturated fatty acids. $9^{\circ}$ For example, bisallylic $\mathrm{C}-\mathrm{H}$ bond in methyl linoleate is considerably weaker than allylic $\mathrm{C}-\mathrm{H}$ bonds as revealed by theoretical calculations of dissociation energies (Scheme 8), 93 which is in line with observed rate coefficients of the propagation step $\left(k_{\mathrm{p}}\right) .{ }^{94}$ In case of polyunsaturated fatty acids, the value of $k_{\mathrm{p}}$ well correlates with number of bisallylic positions..$^{\circ}$ It should be noted that some other factors could influence propagation step of peroxidation (e.g. steric effects, triplet repulsion) but they play minor role in case of fatty acid esters. ${ }^{86,95}$

Distribution of peroxide products appearing upon autoxidation of oleic and linoleic acids esters is shown in Schemes 9 and 10, respectively. Oleic acid esters have two allylic positions with activated $\mathrm{C}-\mathrm{H}$ bonds ( $\mathrm{C} 8$ and $\mathrm{C} 11$ ). Hydrogen atom transfer from either of these positions leads to allyl radical with electron spin distributed on the two terminal carbons. Oxygen addition at these positions results in four kinetic products shown in Scheme 9. In principal, the oxygen addition is a reversible reaction, which facilitates a rearrangement to thermodynamic products with trans-double bonds. ${ }^{86,96}$

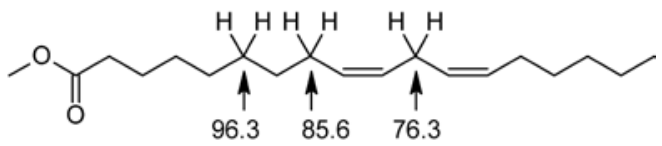

Scheme 8. $\mathrm{C}-\mathrm{H}$ bond dissociation energies (in $\mathrm{kcal} / \mathrm{mol}$ ) for methyl linoleate. ${ }^{93}$

Linoleic acid esters bear one bisallylic position ( $\left.\mathrm{C}_{11}\right)$ with activated $\mathrm{C}-\mathrm{H}$ bonds. The pentadienyl radical, produced through hydrogen atom transfer, has three positons with localized spin density ( $\left.\mathrm{C}_{9}, \mathrm{C}_{11}, \mathrm{C}_{13}\right)$, which may lead to three kinetic products shown in Scheme 10. Peroxyl radical with cis, cis isolated double bonds, formed by oxygen addition to central carbon atom, is highly unstable. Its appearance was evidenced using strong hydrogen radical donor (e.g. $\alpha$-tocopherol), which serves as a very efficient radical trap. At ambient conditions, the radical undergoes rapid rearrangement to more stable cis-trans conjugated isomers. 97 The rearrangement to thermodynamic trans-trans conjugated product is also possible but it is much slower..$^{8}$

Polyunsaturated fatty acids with higher degree of unsaturation exhibit more complex product distribution. For example linolenic acid esters, commonly present in plant oils, do not give only simple hydroperoxides, analogously as linoleic acid, but also diperoxides 99 and endoperoxides. $^{100}$

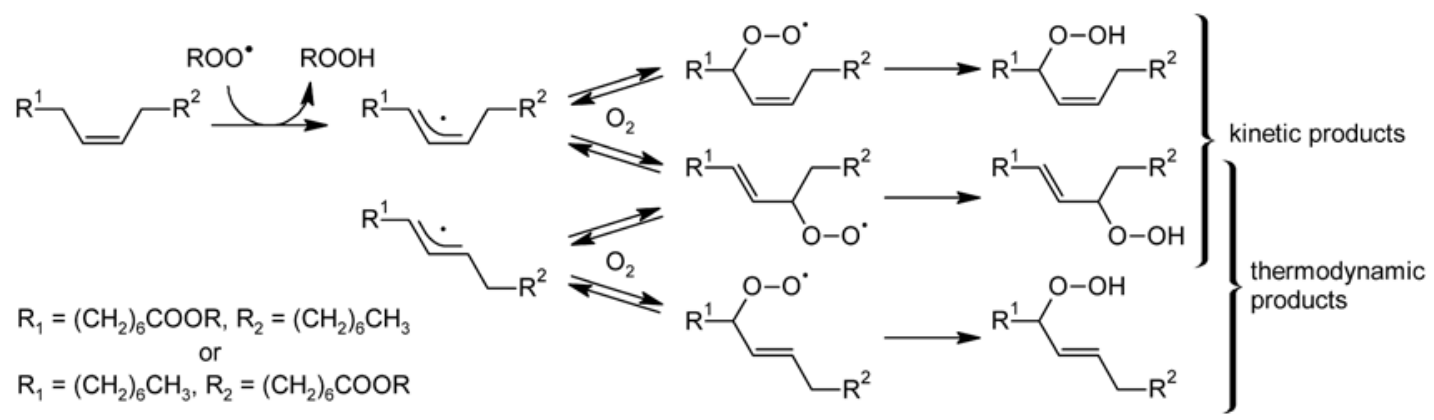

Scheme 9. Peroxidation of oleic acid esters. ${ }^{19,86}$ 


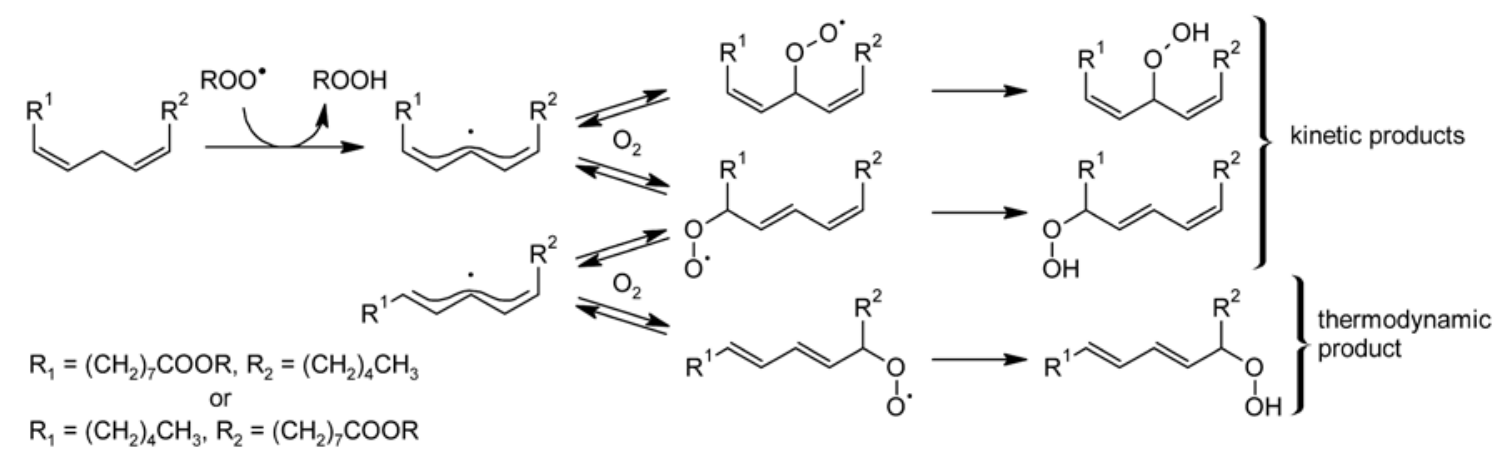

Scheme 1o. Peroxidation of linoleic acid esters. ${ }^{19,86}$

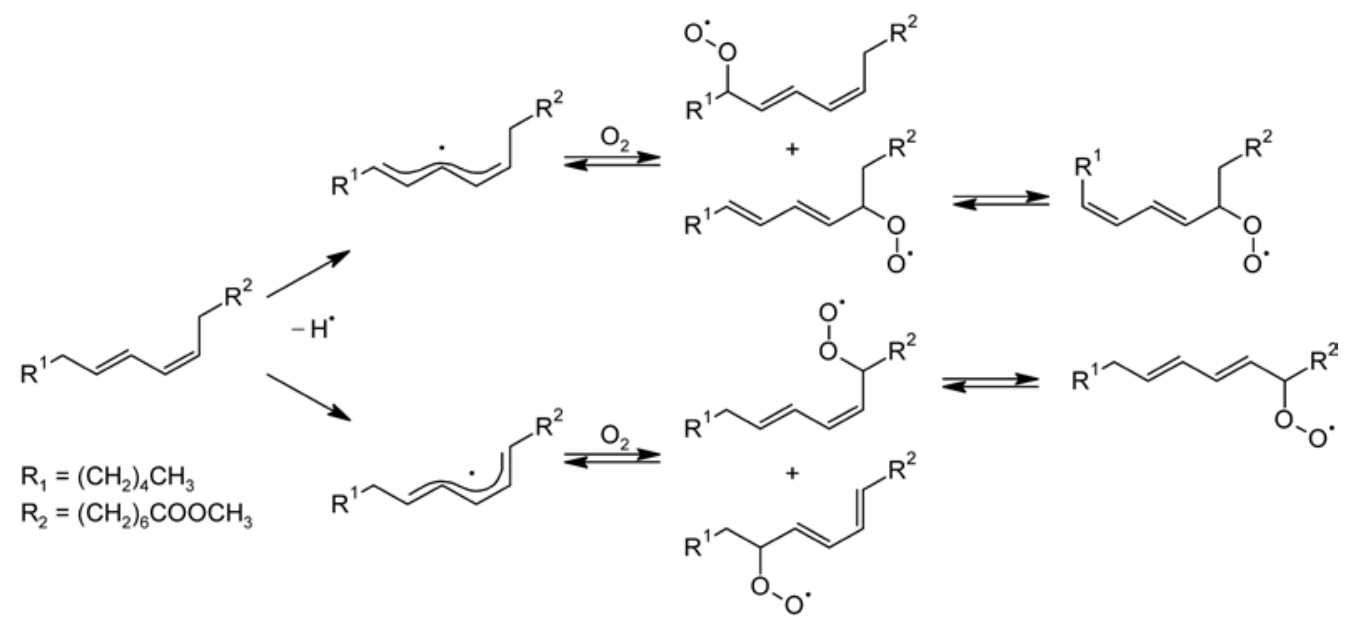

Scheme 11. Peroxyl radicals formed upon autoxidation of 9-cis,11-trans-octadecadienoic acid methyl ester. ${ }^{103}$

So far, mechanism of conjugated fatty acids curing by action of air-oxygen has not been fully clarified. Although various products of autoxidation were isolated, fully consistent reaction mechanism is still missing. ${ }^{101}$ It could be noted that often mentioned 1,4-cycloaddition of molecular oxygen on conjugated double bond system ${ }^{24}$ could not produce endoperoxides without photochemical activation as it violates spin conservation rule. Recent studies on conjugated linoleic acid methyl esters have shown that hydroperoxides are probably formed as primary oxidation products. ${ }^{102,103}$ The peroxidation proceeds though similar mechanism as in case of unconjugated fatty acids. Hydrogen atom transfer from either of two activated methylene groups, shown in Scheme 11, gives pentadienyl radical. Following oxygen addition produces four stable peroxyl radicals those could be trapped by $\alpha$-tocopherol together with some isomerization products.

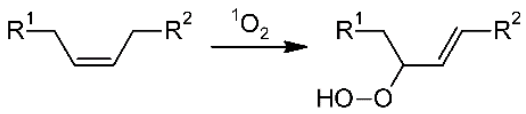

$\mathrm{R}_{1}=\left(\mathrm{CH}_{2}\right)_{6} \mathrm{COOR}, \mathrm{R}_{2}=\left(\mathrm{CH}_{2}\right)_{6} \mathrm{CH}_{3}$ or $\mathrm{R}_{1}=\left(\mathrm{CH}_{2}\right)_{6} \mathrm{CH}_{3}, \mathrm{R}_{2}=\left(\mathrm{CH}_{2}\right)_{6} \mathrm{COOR}$

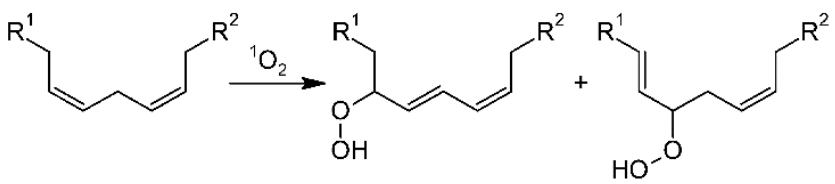

$\mathrm{R}_{1}=\left(\mathrm{CH}_{2}\right)_{5} \mathrm{COOR}, \mathrm{R}_{2}=\left(\mathrm{CH}_{2}\right)_{3} \mathrm{CH}_{3}$ or $\mathrm{R}_{1}=\left(\mathrm{CH}_{2}\right)_{3} \mathrm{CH}_{3}, \mathrm{R}_{2}=\left(\mathrm{CH}_{2}\right)_{5} \mathrm{COOR}$

Scheme 12. Photochemical peroxidation of oleic and linoleic acid esters. ${ }^{104,107}$
Non-radical pathway for peroxidation of unconjugated and conjugated fatty acids involves reaction with molecular oxygen in the first excited singlet state $\left({ }^{1} \mathrm{O}_{2}\right)$ lying 22 $\mathrm{kcal} / \mathrm{mol}$ above the ground triplet state $\left({ }^{3} \mathrm{O}_{2}\right){ }^{104,105}$ Singlet oxygen is not generated by simple thermal processes. Convenient method involves energy transfer from the excited triplet states of aromatic photosensitizers such as rose bengal and methylene blue. The lifetime singlet oxygen is highly solvent dependent and commonly used antioxidants could quench it. ${ }^{106}$

Unconjugated fatty acids undergo "ene" reaction to give a mixture of hydroperoxides (Scheme 12). Interestingly, the rate of peroxidation is proportional to number of allylic methylene groups in the fatty acid chain irrespective to $\mathrm{C}$ $\mathrm{H}$ bond dissociation energy. Therefore, photochemical peroxidation of linoleates is only 1.5 times faster than observed for oleates. ${ }^{107}$ It could be noted that product distribution of linoleate peroxidation is very different from aforementioned radical pathway. Thus, appeared products bearing isolated double bonds can be used to distinguish the singlet oxygen mediated peroxidation process (Scheme 12). ${ }^{104}$ Photochemical oxidation of conjugated fatty acids has not been investigated in detail. It is anticipated that they undergo 1,4-cycloaddition of singlet oxygen to give endoperoxides similarly as other conjugated dienes (Scheme 13). ${ }^{107,108}$

The studies on HS alkyd formulations modified with dehydrated castor oil revealed considerable acceleration of drying process in presence of photosensitizers. The effect 
of singlet oxygen is pronounced at temperatures below $10^{\circ} \mathrm{C}$, where catalytic effect of primary drier, used in mixture with the photosensitizer, is strongly inhibited. ${ }^{107}$ Photoassisted autoxidation was also used on three-component systems consisting of photosensitizer, radical generator and primary drier. ${ }^{87}$

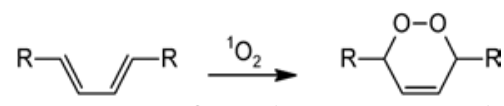

Scheme 13. Reaction of singlet oxygen with conjugated dienes. ${ }^{108}$

\section{Peroxide decomposition and primary driers}

Hydroperoxides are kinetically stable compounds but they undergo homolytic cleavage of the $\mathrm{O}-\mathrm{O}$ bond through action of heat and UV-light (Scheme 14). In air-drying paints, hydroperoxide decomposition is usually accelerated by elevated temperature or transition metal compounds, called primary driers. Formation of alkoxyl (RO') and peroxyl radicals (ROO'), upon metal catalyzed decomposition, is clarified by Haber-Weiss mechanism shown in Scheme $14 .{ }^{23}$ Although it is widely accepted in the academic sphere, recent study on cobalt(II) acetylacetonates and carboxylates has pointed on some anomalies in reaction kinetics, which cannot be clarified by single redox process. ${ }^{109}$ It could be further noted that some authors suggest that particular primary driers (e.g. managanese(III) acetylacetonate or iron 2-ethylhexanaoate/ascorbyl palmitate) could directly accelerate peroxidation process. ${ }^{110-112}$ Nevertheless, such property was unambiguously proven only for lipoxygenase enzymes. ${ }^{88}$ In case of primary driers, the direct effect on peroxidation process is not supported by relevant experiments, probably, due to complications arising from autocatalytic properties of the process.

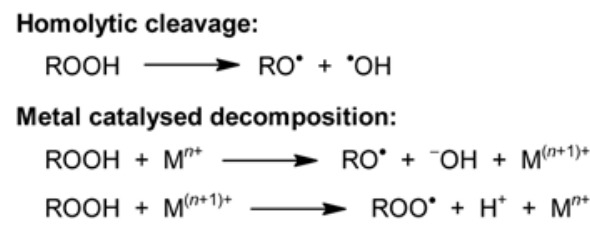

Scheme 14. Peroxide decomposition. ${ }^{23,24}$

Cobalt(II) carboxylates, soluble in organic solvents (e.g. 2-ethylhexanoate aka octoate, naphthenate and neodecanoate aka versetate) are very powerful catalysts of hydroperoxide decomposition. They are used not only as primary driers in paint industry but also in the Du Pont adipic acid synthesis as catalysts for the large-scale autoxidation of cyclohexane to a mixture of cyclohexanol and cyclohexanone (so-called K/A oil). Despite of its importance, molecular structure of active cobalt(II) carboxylates has not been unambiguously clarified. The only relevant study dealing with this issue evidenced various oligomeric $\mathrm{Co}^{\mathrm{II}}$ and mixed valence $\mathrm{Co}^{\mathrm{II}} / \mathrm{Co}^{\mathrm{III}}$ species by use of mass spectrometry in both positive and negative modes. ${ }^{113}$ Nevertheless, it is very likely these are in equilibrium and the active species is not necessary one of these but could be even monomeric.

The catalytic activity of cobalt(II) compounds is strongly affected by subtle changes in the coordination sphere of the metal. For example, coordination of aqua or amine ligands deteriorates performance of cobalt(II) carboxylates, ${ }^{13}$ which has to be taken in account upon storage, selection of additives and formulation of WB paints. Lower activity was reported for cobalt(II) acetylacetonate but, ${ }^{109,114}$ in this case, the performance can be improved be combination with 2-ethylhexanoic acid. ${ }^{115}$

Kinetic behavior of hydroperoxide decomposition in non-polar solvents catalyzed by cobalt(II) compounds is well described by two catalytic cycles proposed by Hermans et al. The classical Haber-Weiss process (Cycle I), involving $\mathrm{Co}^{\mathrm{II}} / \mathrm{Co}^{\mathrm{III}}$ cycling, is accompanied with "Cycle II", in which cobalt stays in formal oxidation state III (Scheme 15). Deactivation of cobalt(II) compounds, observed at high concentration, is ascribed to formation of inactive dimeric species, which cleavage is very slow. Postulated transition into the Cycle II is possible due to strong $\mathrm{Co}^{\mathrm{III}}-\mathrm{OOR}$ bond leading to competition of the bond cleavage with coordination of second hydroperoxide molecule. High activity of cobalt(II) carboxylates is ascribed to a strong preference of Cycle II, which is further driven by small ligand cone angle. Lower active cobalt(II) acetylacetonate remains predominantly in Cycle I. ${ }^{109,116}$ It is interesting that the key intermediate $\mathrm{Co}^{\mathrm{III}} \mathrm{OOR}$, involved in deperoxidation process, can be stabilized by $N$-donor ligands, which enables its isolation in crystalline form and detailed investigation. ${ }^{17}$ This approach has been utilized to elucidate the molecular structure of acetylacetonate derivatives. ${ }^{118}$

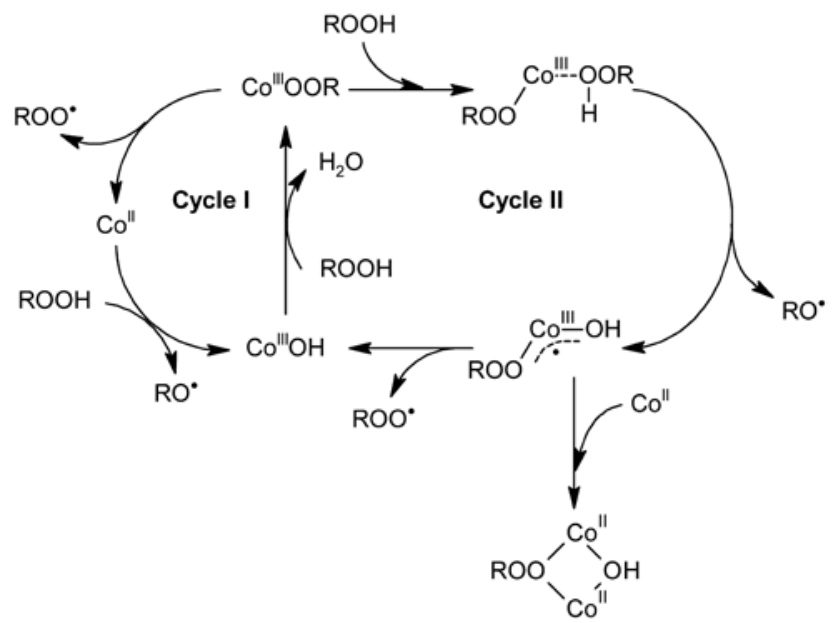

Scheme 15. Mechanism of cobalt(II) catalyzed deperoxidation. ${ }^{109}$

In contrary to common belief, 13,24 the common cobalt compounds, do not activate curing process photocatalytically. Negligible role of UV radiation on curing process was documented on alkyd formulations treated with cobalt(II) carboxylates. ${ }^{107}$ Singlet oxygen generation with high quantum yields was reported only for cobalt(II) compounds bearing photoactive anthracenyl and pyrenyl moieties. ${ }^{119}$ It could be noted that mechanism, outlined in Scheme 15, is also relevant to WB formulations of air-drying paint. Although one may suggest pathway derived from cobalt-catalyzed decomposition of hydrogen peroxide, which proceeds in aqueous solution and involves predominantly cobalt(II) species, ${ }^{120}$ the earlier approach is more relevant for 
WB paints as the binder autoxidation proceeds in non-polar alkyd phase after water evaporation. ${ }^{121}$

Cobalt(II) 2-ethylhexanoate, is the most extensively used primary drier in paint-producing industry, mainly due to its high catalytic power and low price. The studies dealing with investigation of autoxidation process or development of novel driers usually take cobalt(II) 2-ethylhexanoate as a "golden standard". The main drawback of cobalt-based driers is their toxicity. ${ }^{15}$ Soluble cobalt compounds were found to be genotoxic and carcinogenic. They cause chemical DNA damage through generation of free radicals form hydrogen peroxide. ${ }^{16,122}$ Less pronounced drawback of the cobalt(II) carboxylates is relatively high sensitivity to proper dosage, which is significant mainly in case of HS binders. Overdose effect often causes paint defects (e.g. wrinkling and orange peel), which originates from fast curing of the surface while the inner part of the coating stays intact. At concentrations lower than optimal, the drying time increases rapidly due to long induction times. ${ }^{14}$ In practice, the high-sensitivity to drier concentration is solved by use of additives called secondary driers (i. e. carboxylates of redox-inactive metals), which improve trough-drying of the paint coating. ${ }^{123}$

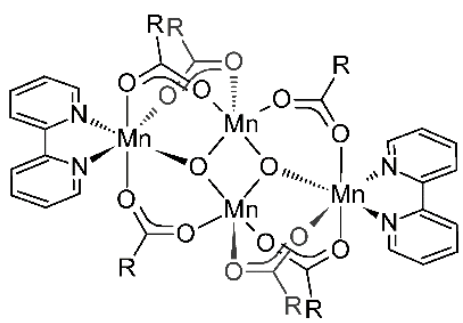

A

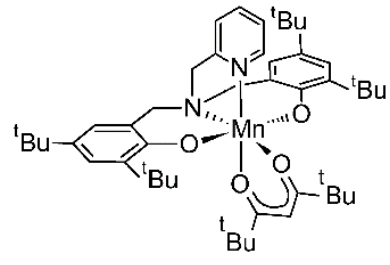

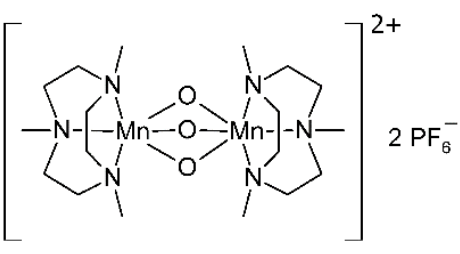

C

Scheme 16. Structure of complexes bearing chelating ligands: A) complex isolated from the mixture manganese(II) 2ethylhexanoate/2,2'-bipyridine, ${ }^{126} \mathrm{~B}$ ) highly-soluble complex bearing a tripodal tetradentate ligand, $\left.{ }^{127} \mathrm{C}\right)$ water-soluble dinuclear manganese(IV)-manganese(IV) complex. ${ }^{128}$

Non-cobalt primary driers are usually based on carboxylates or coordination compounds of manganese, iron, vanadium or cerium. Redox properties of these compounds enable to decompose hydroperoxides through HaberWeiss mechanism but detailed kinetic studies, excluding alternative catalytic cycles, are still missing.

Commercial manganese(II) 2-ethylhexanoate and neodecanoate are obvious alternatives for cobalt-based driers but they exhibit considerably lower activity that is further inhibited at high relative humidity. Another weak point of manganese-based driers is their dark brown color that shifts coloration of transparent and pale-pigmented formulations. ${ }^{124}$ Improved drying properties were reported for formulations treated with various $N, N$-chelating ligands. ${ }^{125}$ Detailed investigation of the coordination behavior of manganese revealed appearance of tetranuclear $\mathrm{Mn}_{2}{ }^{\mathrm{II}} / \mathrm{Mn}_{2}{ }^{\mathrm{III}}$ species (Scheme 16 , Structure A), which is responsible for increased activity of 2,2'-bipyridine derivative. ${ }^{113,126}$

Promising drying activity was also reported for manganese(III) acetylacetonate $\left[\mathrm{Mn}(\mathrm{acac})_{3}\right]$ and its combinations with various chelating ligands. ${ }^{110,111,129}$ High reaction rates, observed for the systems with $N, N$-chelating ligands $\left({ }^{N}, \mathrm{~N} L\right)$ established on ethyl linoleate model system, are explained by facilitated reduction of $\mathrm{Mn}^{\mathrm{III}}$ to $\mathrm{Mn}^{\mathrm{II}}$ producing stable $\left[\mathrm{Mn}^{\mathrm{II}}(\text { acac })_{2}\left({ }^{\mathrm{N}, \mathrm{N}} \mathrm{L}\right)\right]$ complexes. ${ }^{111,130}$ Unfortunately, following experiments on alkyd formulations did not prove the positive effect of chelating ligands, which is attributed to extensive $\beta$-scission side reactions producing volatile side products and thus lower degree of crosslinking. ${ }^{124}$ It should be also noted that application of $\left[\mathrm{Mn}(\mathrm{acac})_{3}\right]$ in real paints is very limited by low solubility in organic solvent.

Further experiments on model systems demonstrated promising catalytic activity for manganese(III) compounds bearing tetradentate tripodal $\mathrm{N}, \mathrm{N}, \mathrm{O}, \mathrm{O}$-chelating ligands. Potential for application was suggested for derivative bearing non-polar tert-butyl groups (Scheme 16, Structure B), which exhibits good catalytic performance and excellent solubility in organic solvents. ${ }^{127}$

Strong application potential have been recognized for dinuclear $\mathrm{Mn}^{\mathrm{IV}}-\mathrm{Mn}^{\mathrm{IV}}$ complex bearing 1,4,7-trimethyl-1,4,7triazacyclononane ( $\mathrm{Me}_{3} \mathrm{TACN}$; Scheme 16, Structure C), which was originally designed as a catalyst improving bleaching power of peroxides at low temperature. ${ }^{128,131}$ Initial experiments on ethyl linoleate emulsions, utilized as a model for WB formulation, revealed considerably higher drying activity than reported for manganese(II) carboxylates, which could be further enhanced by addition of polyamine (e.g. 1,1,4,7,10,10-hexamethyltriethylenetetramine). ${ }^{132,133}$ Such additive apparently facilitates phase transfer and migration of the dicationic catalyst close to nonpolar fatty-acid chains where the autoxidation proceeds. The catalytic performance of the dinuclear species is clarified by modified Haber-Weiss process shown in Scheme 17. It could be noted that all dimeric species given in the scheme have been detected by mass spectrometry. ${ }^{133}$ The appearance of intermediate $\mathrm{Mn}^{\mathrm{III}}-\mathrm{Mn}^{\mathrm{IV}}$ species was further evidenced by EPR spectroscopy. ${ }^{134}$ Following study on SB and WB formulations verified high activity at concentration level comparable to cobalt carboxylates and noted acceptable color change.135 Modified manganese species bearing $\mathrm{Me}_{3} \mathrm{TACN}$ ligand is currently commercially available. It performs at considerably lower concertation level than cobalt(II) carboxylates and the paint films are cured more homogenously..$^{136}$ 


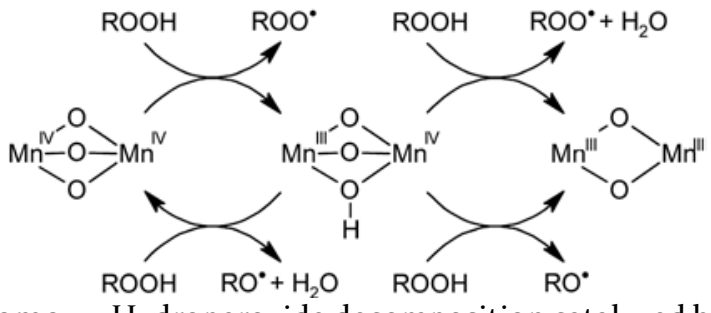

Scheme 17. Hydroperoxide decomposition catalyzed by dinuclear manganese complex. ${ }^{133}$

Iron based driers have been deeply scrutinized since iron is a low-toxic metal possessing pronounced $\mathrm{Fe}^{\mathrm{II}} / \mathrm{Fe}^{\mathrm{III}}$ redox system. The initial studies on iron 2-ethylhexanoate reported negligible activity at room temperature and possible application in baking emails. Following investigation revealed that iron 2-ethylhexanoate forms trinuclear clusters with two equivalent iron(III) sites and one unique iron(III) site (Scheme 18). ${ }^{112,113}$ Its low activity is ascribed to high redox-stability of $\mathrm{Fe}^{\mathrm{III}}$ in the structure, which brakes Haber-Weiss cycle. The catalytic activity can be induced by an excess of ascorbyl fatty acid esters promoting iron(III) reduction. ${ }^{137,138}$ Although structure of the reduced cluster was not fully elucidated, it was sufficiently documented that only one iron site is effectively redox-active. ${ }^{112} \mathrm{Oxi}^{-}$ dized ascorbyl ester is probably coordinated on active site of the cluster but detailed mechanism of the catalytic action deserves further investigation. The activity of the catalytic system was documented on SB formulations including fully pigmented paint containing all necessary additives. It could be noted that simplified system iron(II) sulfate / ascorbic acid is not suitable even to WB formulations owing to limited solubility in the paint system after water evaporation. ${ }^{37}$ It could be further noted that high concentration of ascorbic acid derivatives should be avoided in air-drying paints as it may lead to inhibition of the autoxidation process due to their pronounced antioxidant activity.

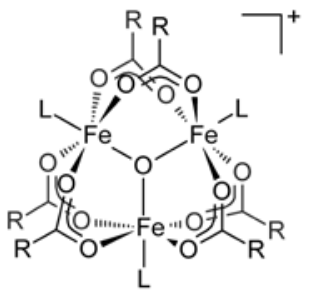

A

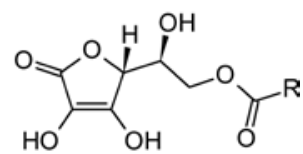

B
Scheme 18. Molecular structure of A) iron carboxylates where L is coordinated solvent molecule; B) ascorbyl carboxylate. ${ }^{112}$

High drying activity is reported for iron-bispidine complex shown in Scheme 19.139 The rigid framework of the pentadentate bispidine ligand enforces specific geometric constrains hardly accessible by another simple ligands. The unique coordination sphere of iron mimics the active site of lipoxygenases (Scheme 19); non-heme iron enzymes responsible for lipid oxidation in biological systems. ${ }^{88}$ Although the species was originally developed as a catalyst for textile bleaching, ${ }^{131}$ later scrutiny revealed strong drying ac- tivity in SB, WB and HS alkyd formulations at concentrations about two orders of magnitude lower than commonly used in case of cobalt(II) carboxylates. ${ }^{14,136,139,140}$ Due to low solubility in common organic solvents, the commercial iron-bispidine complex is usually supplied as a solution in water or 1,2-propanediol. Recently, the solubility issue has been overcame by exchange of chloride ${ }^{141}$ ligands by nonpolar 2-ethylhexanotates. ${ }^{141,142}$ It could be noted that mechanism of the iron-bispidon catalyzed curing has not been fully clarified. Beside obvious Haber-Weiss peroxide decomposition, suggested in coating studies, ${ }^{141}$ the catalyst could be also responsible for acceleration of peroxidation process involving iron $\mathrm{Fe}(\mathrm{IV})$ intermediate. ${ }^{143}$

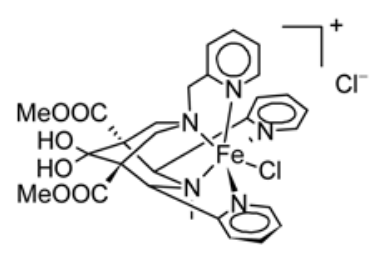

A

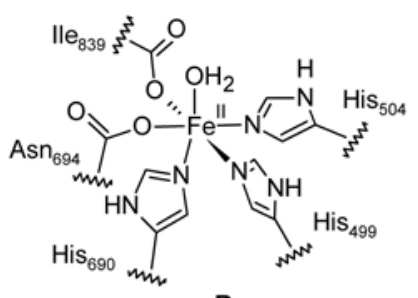

B
Scheme 19. A) Molecular structure of iron-bispidine complex; ${ }^{144}$ B) active site of lipoxygenase protein. ${ }^{88}$

Ferrocene and its derivatives were subject of several studies dealing with air-drying paints. The initial investigation on ethyl linoleate, which was taken as a model system of alkyd paint, reports a very promising kinetics of the autoxidation process mainly for octamethyl and decamethyl derivatives. ${ }^{145}$ Although following study on commercial alkyd binder revealed rather inhibitive properties of unmodified ferrocene, ${ }^{146}$ it allows partial replacement of cobalt(II) 2-ethylhexanoate. ${ }^{147}$ Similar synergy with the cobalt-based drier was further evidenced for various ferrocene derivatives. ${ }^{166,147}$ The detailed testing on alkyd binder modified with TOFA revealed high activity of acyl-substituted ferrocenes. These derivatives allow full cobalt replacement as they exhibit strong catalytic activity at similar metal concentration a commercial cobalt-based driers. Among them, benzoylferrocene (Scheme 20) seems to be the most promising for industrial application as it is readily available and its activity was confirmed on slower-drying resin modified by soybean oil. ${ }^{148}$

It could be noted that ferrocene performs as a purely redox-active drier not involving coordination of hydroperoxide or another component of the reaction mixture. Similar behavior is expected for iron-helmet-phthalocyaninate complex (Scheme 20), which allows only very weak solvent coordination. Although catalytic behavior of the iron complex bearing phthalocyaninate-like ligand is known for decades, it was initially ascribed to another complex species. ${ }^{149}$ The structure redetermination revealing helmetlike ligand structure appeared very recently ${ }^{150,151}$ and several experiments, performed on model systems, suggest considerably stronger catalytic power than in case of cobalt(II) 2-ethylhexanoate, which seems to be very promising but deserves more detailed investigation on a full alkyd paint. ${ }^{51}$ 


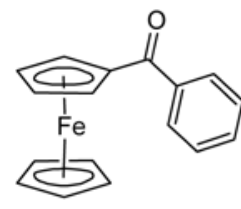

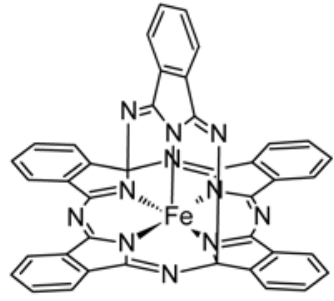

B
Scheme 2o. Molecular structure A) of benzoylferrocene; ${ }^{148}$ B) iron-helmet-phthalocyaninate complex. ${ }^{151}$

Oxovanadium compounds are known as the potent oxidation catalysts for many decades but detailed investigation of their catalytic performance in air-drying paints began only recently. Readily available oxovanadium(IV) acetylacetonate (Scheme 21) shows promising activity in SB alkyd paints. It performs at about one-third of concentration common for cobalt(II) 2-ethylhaxanoate. ${ }^{152}$ Solubility issue, which appears in non-polar solvents, was overcome by modifications of acetylacetonate ligands by alkyl substituents. ${ }^{153}$ High catalytic activity in SB binders was also reported for oxovanadium(IV) 2-ethylhexanoate 154 and for oxovanadium(IV) complex stabilized by tetradentate macrocyclic ligand (Scheme 21). ${ }^{155}$ It could be noted that oxovanadium(IV) 2-ethylhexanoate has an oligomeric structure in stock solution but dissolution in alkyd resin led to slow splitting producing mononuclear species as evidenced by EPR spectroscopy. ${ }^{154}$ Performance of vanadiumbased driers could be clarified by classical Haber-Weiss mechanism involving $\mathrm{V}^{\mathrm{IV}} / \mathrm{V}^{\mathrm{V}}$ redox system, which was elucidated from electrochemical studies on oxovanadium(IV) acetylacetonate..$^{152}$ Appearance of $\mathrm{V}^{\mathrm{IV}}$ species was observed also in dried alkyd films cured with oxovanadium(V) dithiocarbamates (Scheme 21), which further supports the participation of $\mathrm{V}^{\mathrm{IV}} / \mathrm{V}^{\mathrm{V}}$ redox cycle. ${ }^{156}$

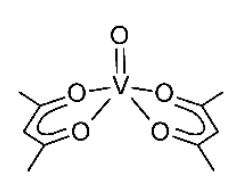

A

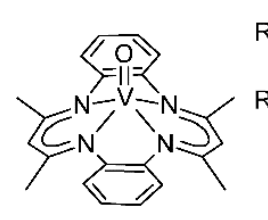

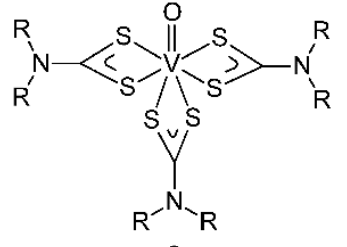

C
Scheme 21. Molecular structure of A) oxovanadium(IV) acetylacetonate; 152 B) oxovanadium(IV) complex bearing Geodken's macrocycle,;15 C) oxovanadium(V) dialkyldithiocarbamate. ${ }^{15}$

\section{Crosslinking reactions and side products}

Conversion of liquid air-drying paint layer to crosslinked coating proceeds predominantly through radical addition to conjugated double bond system (Scheme 22) and radical recombination reactions (Scheme 23). In principle, the crosslinking reaction may involve all types of radicals produced upon aforementioned peroxidation and deperoxidation processes ( $\mathrm{R}^{\circ}, \mathrm{RO}^{\circ}$ and $\left.\mathrm{ROO} \mathrm{O}^{\circ}\right)$. In practice, however, alkyl radicals $\left(R^{*}\right)$ do not participate on these processes due very low concentration caused by fast reaction with air-oxygen.

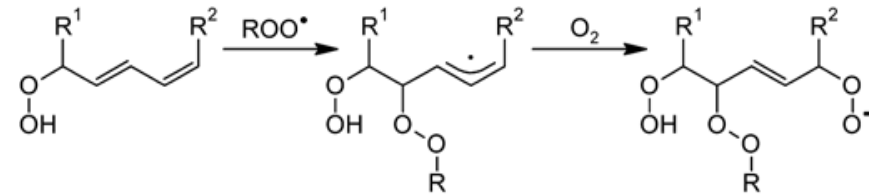

Scheme 22. Example of radical addition followed by oxygen addition. 157

The addition mechanism considerably predominates at early stage of the autoxidation process when concentration of conjugated double bonds is high. Appeared allylic radical is highly reactive undergoing oxygen addition at nearly diffusion controlled rate. ${ }^{157}$ Participation of this crosslinking pathway is evident from appearance of higher oligomers of ethyl linoleate not available solely through radical recombination. ${ }^{1{ }^{8}}$ Vibrational spectroscopy enables to follow the radical addition process in alkyd resin through developments of vibration modes characteristic for conjugated double bond system. . $^{14,159}$

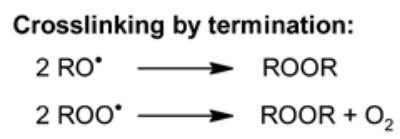

Termination involving hydrogen atom transfer:

$2 \mathrm{R}^{\prime} \mathrm{R}^{\prime C} \mathrm{CHOO} \longrightarrow \mathrm{R}^{\prime} \mathrm{R}^{\prime \prime} \mathrm{C}=\mathrm{O}+\mathrm{R}^{\prime} \mathrm{R}$ " $\mathrm{CHOH}+\mathrm{O}_{2}$

Deperoxidation reaction:

$2 \mathrm{ROO}^{*} \longrightarrow 2 \mathrm{RO}^{*}+\mathrm{O}_{2}$

$\mathrm{RO}^{*}+\mathrm{ROOH} \longrightarrow \mathrm{ROH}+\mathrm{ROO}^{*}$

Scheme 23. Crosslinking through radical recombination and selected concurrent reactions. ${ }^{91,109}$

Self-reaction of alkoxyl radicals (RO') plays a minor role in crosslinking process owing to their high reactivity. Furthermore, the alkoxyl radicals undergo scission reactions producing volatile organic products, predominantly aldehydes, responsible for characteristic odor of air-drying paints. ${ }^{3}$ In case of linoleic acid, the $\beta$-scission of chain ends from oligomeric RO' species seems to be the largest contributor of hexanal emission, which is considered as a major volatile product (Scheme 24). ${ }^{157}$ Carbonyl groups attached to the polymer substrate are responsible for effect called "dark yellowing", which appears on aged coatings of air-drying binders kept in dark. Yellow chromophores are predominantly formed by condensation reactions with atmospheric nitrogen-containing pollutants (e.g. ammonia). Such yellowed coatings can be partially rebleached by action of daylight. The visible-light irradiation probably decolorizes the chromophores through addition of RO* radicals generated through homolytic cleavage of labile peroxo crosslinks in the cured coatings. ${ }^{160}$ 


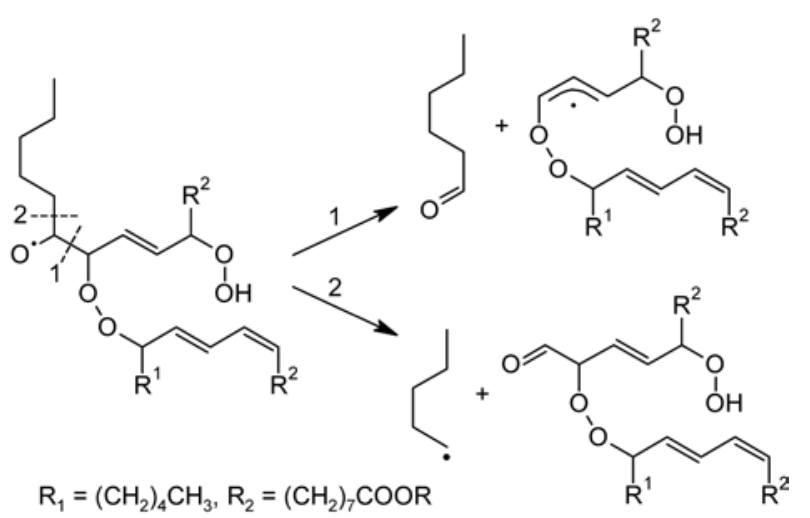

Scheme 24. Example of $\beta$-scission reaction of oligomeric linoleate. ${ }^{157}$

Recombination of peroxyl radicals ( $\mathrm{ROO}^{\circ}$ ) gives unstable tetroxide (ROOOOR), which can produce peroxo crosslinks between fatty acid chains (Scheme 23). However, the tetroxide decomposition is a complex process involving several concurrent reactions with different outcome. As clarified in recent computational study, the first step of the tetroxide decomposition involves two consecutive $\mathrm{O}-\mathrm{O}$ bond cleavages leading to two $\mathrm{RO}^{*}$ and $3 \mathrm{O}_{2}$ caged by solvent. Such $\mathrm{RO}^{\circ}$ radicals cannot recombine easily as their unpaired electrons have the same spin making the crosslinking reaction spin-forbidden. Preferably, the caged RO' radicals undergo hydrogen atom transfer to give ketone and alcohol.91 Such products are formed in nearly equal amounts as proved experimentally. It could be noted that formation of ketone/alcohol mixture does not proceeds by widely accepted intramolecular rearrangement, known as Russell mechanism, ${ }^{161}$ owing to considerably high energetic barrier..$^{1}$ The $\mathrm{RO}^{*}$ radicals may, of course, escape the cage and recombine with another $\mathrm{RO}^{*}$ or attack hydroperoxide $(\mathrm{ROOH})$. Later pathway leads to peroxide decomposition as overall reaction becomes ( $\left.2 \mathrm{ROOH} \rightarrow \mathrm{O}_{2}+2 \mathrm{ROH}\right)$. At high radical concentration, such process can concur to metal-catalyzed deperoxidation (Scheme 14) ${ }^{109}$ and could clarify deceleration of autoxidation observed at high drier concentrations. Nevertheless, the overdose effect in paint formulation is more often caused by skin formation decelerating oxygen diffusion into the film. ${ }^{14}$

Ketone side products, mentioned above, are not formed exclusively within the termination step but also by hydrogen atom transfer from $\alpha$-position to hydroperoxide group (Scheme 25). The decomposition of transient C-centered radical is accompanied by formation of highly reactive hydroxyl radical $\left(\mathrm{HO}^{\circ}\right){ }^{162}$ Its appearance seems to be of particular importance as may lead to unexpected secondary products.

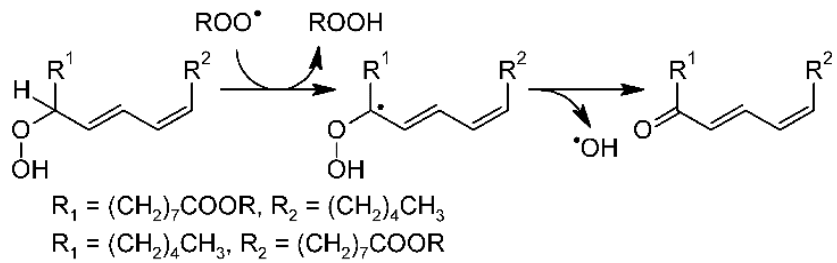

Scheme 25. Mechanism of hydroxyl radical formation. ${ }^{162}$
It could be noted that recombination of $\mathrm{ROO}^{\circ}$ and $\mathrm{RO}^{\circ}$ radicals does not produce ether crosslinks and $\mathrm{O}_{2}$, suggested by several authors, ${ }^{24}$ as the process should involve high-energy $\mathrm{C}-\mathrm{O}$ bond splitting. Furthermore, care could be take upon interpretation of experiments, performed on tertiary hydroperoxides, as they are generally more stable and do not possess all reaction pathways available for secondary hydroperoxides (e.g. fatty acid hydroperoxides). ${ }^{91}$

Early-states of the crosslinking process can be followed by spatial resolved NMR imaging as decrease in the molecular mobility is related with relaxation times. ${ }^{136,163}$ However, it could be stressed that curing of air-drying paints is a long-term process. Although peroxidation process, mentioned in previous section, is usually complete within hours, crosslinking and side-reactions proceed in term of weeks and months as documented by developments of relative hardness, ${ }^{152}$ modulus density and mass decrease. ${ }^{164}$ Slow termination of the autoxidation process is due to immobilized radicals caged in the polymeric matrix. Furthermore, the cured films contain many unstable peroxo bridges those can dissociate to $\mathrm{RO}^{*}$ radicals by action of light or heat. Final stages of curing can led to embrittlement and aging as the polymer degradation is based on some kind of autoxidation process as well. ${ }^{165}$

In summary, curing of air-drying paints is a very complex process. At current stage of art, its detailed kinetics can be approached only by mechanistic models available by automating the process of network generation. ${ }^{166,167}$ Recent microkinetic model for the autoxidation of ethyl linoleate catalyzed by cobalt(II) 2-ethylhexanoate, well reproduces the key reaction outcome and enables to explore effect of temperature and catalyst concentration. ${ }^{167}$

\section{Antiskinning agents}

Autoxidation of air-drying paints has to be avoided upon their production and storage. The undesired curing is usually noticed as a polymeric film on surface of liquid paint, which is prevented by compounds known as "antiskinning agents". ${ }^{168}$ Phenolic compounds (e.g. t-butylhydroquinone, 2(3)-t-butyl-4-hydroxyanisole, 2,6-di-tert-butyl-4methylphenol, 4-hexylresorcinol and $\alpha$-tocopherol) are radical-trapping antioxidants commonly used for inhibition of autoxidation processes responsible for degradation of polymeric materials and food products. They break peroxidation process through hydrogen transfer from phenolic hydroxyl producing phenoxyl radical that is stabilized by resonance. It is inactive to bisallylic $\mathrm{C}-\mathrm{H}$ bonds but readily captures second peroxyl radical as shown on example of 2,6-di-tert-butyl-4-methylphenol in Scheme $26 .{ }^{169,170}$

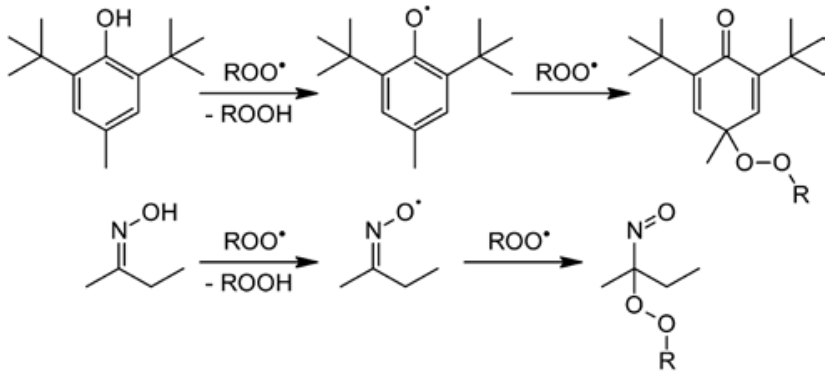


Scheme 26. Radical trapping by A) phenolic antioxidant ${ }^{169}$ and B) MEKO. ${ }^{17}$

Although highly effective, phenolic antioxidants are not very suitable for air-drying paints, as their optimal dosage is hard to estimate. Hence, excess of the phenolic antioxidants strongly inhibit the autoxidation process even in coated films, which results in considerably prolonged drying times. This drawback is overcome by volatile butanone oxime, known as MEKO, which is evaporated in early stage of drying and have only minor effects on film-formation process. ${ }^{168,171}$ Similarly as in case of phenolic antioxidants, ketoximes perform as radical-trapping antioxidants; one molecule of the agent deactivates two chain-carrying radicals (Scheme 26). ${ }^{171}$ Less volatile cyclohexanone oxime is recommended for fast drying binders (e.g. tung oil based binders) where deceleration of curing process is beneficial as it helps to prevent premature film-formation and appearance of related paint defects.

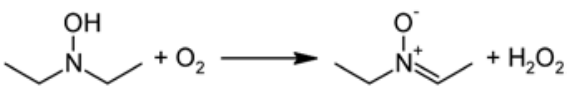

Scheme 27. Oxygen trapping by DEHA in aqueous media. ${ }^{172}$

It should be noted that ketoximes are currently classified as a suspected carcinogens and search for less toxic alternatives is ongoing. ${ }^{173}$ Although various approaches preventing paint skinning were suggested in patent literature, only $N, N$-diethylhydroxylamine, known as DEHA, reached a commercial use in paint-producing industry. ${ }^{174}$ In aqueous solutions, DEHA performs as oxygen scavenger producing nitrone and hydrogen peroxide under mild conditions (Scheme 27). ${ }^{172}$ In non-aqueous media, however, such reaction pathway is not available and DEHA probably performs as volatile radical trapping agents. ${ }^{175}$ Nevertheless, mechanism of the action in paint systems deserves detailed investigation.

\section{Secondary driers}

Fine-tuning of autoxidation process is usually not done by strong antioxidants or oxygen scavengers but by metal carboxylates soluble in organic solvents known as secondary driers. Such compounds are not catalytically active themselves but can improve performance of primary drier. ${ }^{176}$ It should be noted that secondary driers are often sorted on "through driers" and "auxiliary driers" but this classification is not recommended, as mechanism of their action is not fully understood on the molecular level and could be very different among each group. ${ }^{23}$ Commonly used secondary driers include 2-ethylhexanoates of lithium, potassium, calcium, strontium, zirconium, zinc, aluminum and bismuth. They do not influence only drying time, through drying and film hardness but can also reduce formation of skin and paint defects, improve coating gloss, durability, color-retention, pigment-wetting properties and performance at low temperatures and high air-humidity. ${ }^{176}$ Such performance is attributed to many working mechanisms (e.g. co-catalysis due to Lewis acidic properties, improved oxygen uptake, crosslinking through carboxylic group coordination, deceleration of autoxidation on surface leading to better trough drying, coordination of pigment particle those may deactivate primary drier) but only few of them are supported by hard experimental data. ${ }^{24,177}$

Recent investigation compared performance of popular drier combinations $\mathrm{Co} / \mathrm{Zr}, \mathrm{Co} / \mathrm{Ca}$ and $\mathrm{Co} / \mathrm{Zr} / \mathrm{Ca}$ and with similar systems containing manganese and iron-based primary driers. It has proved that both secondary driers effectively reduce induction period of the curing process, both on the surface and the bottom of the film. The main function of calcium 2-ethylhexanoate involves improvement of through drying due to increasing oxygen permeability while zirconium 2-ethylhexanoate enhances crosslinking density probably due to carboxylic group coordination. ${ }^{123}$

\section{Curing of oriental lacquers}

Oriental lacquers and their synthetic congeners are cured by action of air-oxygen but mechanism of the filmformation differs considerably from the oil-based air-drying paints. It is due to antioxidant behavior of the phenolic compounds inhibiting autoxidation process on lipid tail. ${ }^{169,178}$ The oriental lacquers undergo enzymatically catalyzed oxidative polymerization. Alternative curing procedures involve thermal treatment enforced by iron(II) acetate ${ }^{179}$ and UV-curing of the lacquer solution in reactive solvent. ${ }^{71}$ In the first step of the polymerization, catechol moieties of urushiol, laccol and thitsiol are oxidized to semiquinone radicals. Such radical species are stabilized by resonance but readily attack another catechol moiety to give a mixture of biphenyls undergoing subsequent oxidation to dibenzofuran derivatives (Scheme 28). The second important pathway involves attack of semiquinone radical on double bonds of lipid tails, which produces carbon-carbon and carbon-oxygen-carbon crosslinks (Scheme 28). ${ }^{69,180,181}$ In case of thitsiol, the earlier pathway is strongly preferred due to low content of highly reactive conjugated double bonds in the side alkyl chains. ${ }^{182}$ 


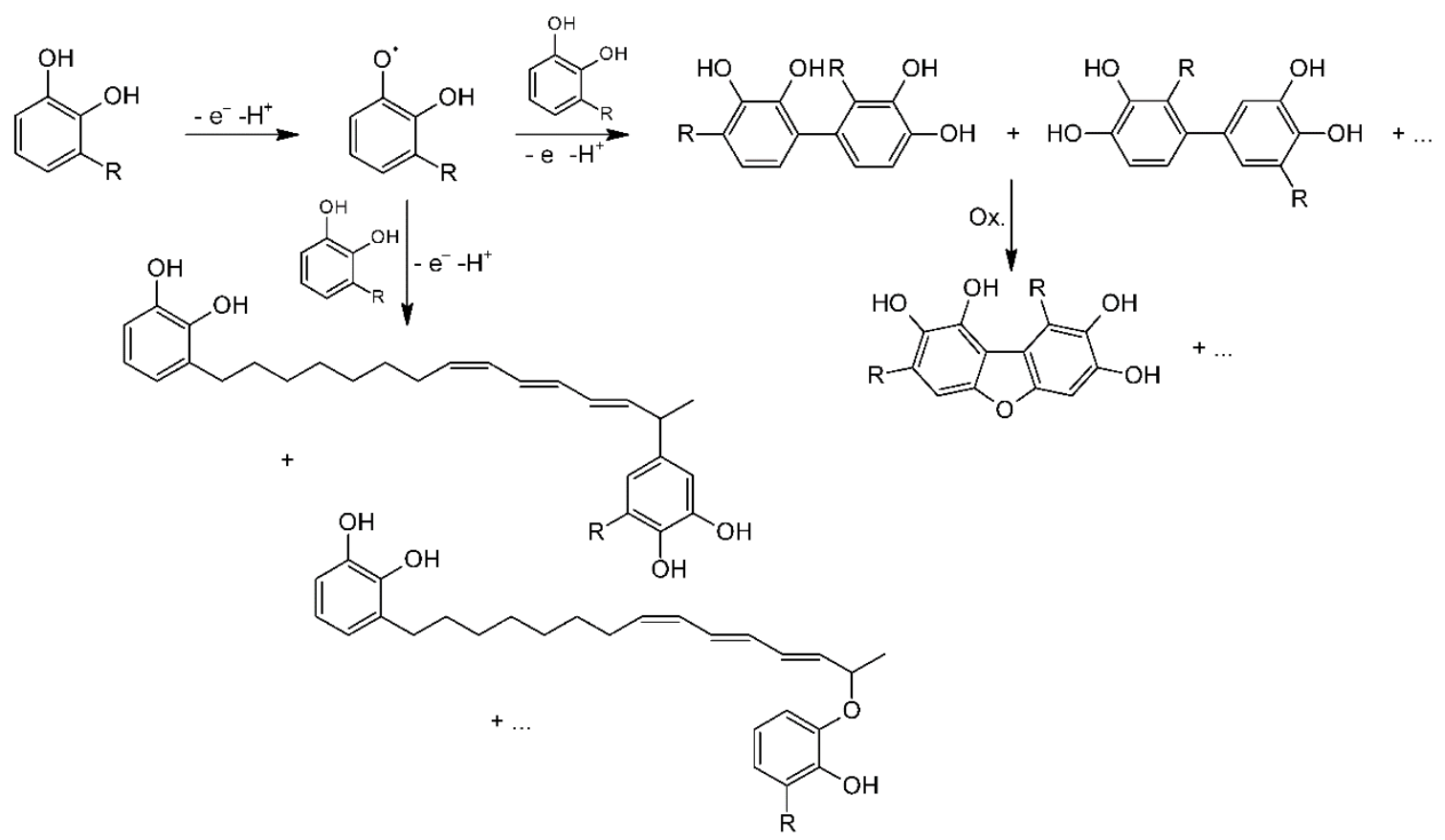

Scheme 28. Oxidative polymerization of oriental lacquers. ${ }^{69,180}$

Although autoxidation of lipid tails is inhibited in phenolic lacquers, it contributes to final properties of cured coatings. Hence, extensive autoxidation starts when phenolic hydroxyl groups are consumed. ${ }^{183}$ The participation of autoxidation process on crosslinking of the phenolic resins strongly depends on degree of unsaturation. Interestingly, the studies on hydrogenated urushiol proved that the crosslinking solely through catechol coupling reactions is satisfactory to reach durable coating with good mechanic properties. ${ }^{184}$

Oxidative polymerization of oriental lacquers is catalyzed by laccase enzymes naturally occurring in the lacquer tree sap. Laccase of Toxicodendron vernicifluum, responsible for urushiol polymerization, contains four copper ions at three different sites; all of them essential for the redox catalysis. ${ }^{185}$ Synthetic catechol derivatives, used for preparation of artificial urushi, are curable by fungal laccase derived from Pycnoporus coccineus. ${ }^{7,186}$ However, laccase catalyzed oxidation polymerization does not occur in case of 4-substituted phenols.7 Another procedure for curing of artificial urushiol analogues involves treatment by hydrogen peroxide in presence of iron-salen complex (Scheme 29), which was developed as a model system for peroxidase enzymes. ${ }^{187}$ The oxidation polymerization gives substituted polyphenylene oxide, in which unsaturated side chains stay untouched as evidenced on various urushiol analogues including CNSL. Such prepolymers seems to be very suitable for formulation of air-dying paint since autoxidation can proceed on the side chains in presence of primary driers as evidenced on cobalt(II) naphthenate.7,78,79 Until now, the attempts to use other catalysts were only partially successful as modified iron-salen compounds, transition metal acetylacetonates and transition metal phthalocyanine complexes show considerably lower activity that the original iron-salen complex..$^{81}$
Scheme 29. iron-salen complex. ${ }^{187}$

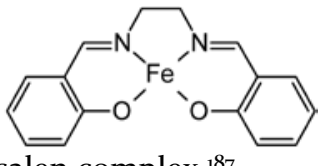

\section{Concluding Remarks}

Although the oil-based paints and oriental lacquers are extensively used for thousands of years, there is still number of questions about mechanism of their curing on molecular level even through large development was achieved in last few decades. This review documents substantial progress in the field and points out on several oversimplifications and inconsistencies with current state of knowledge those are deep-seated in the community of coating technology. It also covers latest development in the field of catalysts used for acceleration of air-drying process including replacement of currently used cobalt compounds with more environmentally sustainable alternatives. It could be noted that several subjects related with air-drying paints deserve in-depth investigation. Such quests involve cultivation and production of new oil-giving plants, development of WB and HS binders with improved performance, replacement of cobalt-based driers and butanone oxime with less toxic alternatives. Additional theoretical and experimental studies are necessary to clarify mechanism of plant-oil polymerization in absence of air, autoxidation of conjugated fatty acid esters and activity of secondary driers. Furthermore, advanced kinetic models could be very useful for quantifying the roles of crosslinking reactions, termination reactions, decomposition side reaction, the effects of driers, oxygen diffusion and coating thickness in the real paint systems.

\section{AUTHOR INFORMATION}

\section{Corresponding Author}


*E-mail: jan.honzicek@upce.cz.

\section{ABBREVIATIONS}

CNSL, cashew nutshell liquid; DEHA, N,N-diethylhydroxylamine; HS, high-solid; IV, iodine value; OL, oil length; MEKO, butanone oxime; $\mathrm{Me}_{3} \mathrm{TACN}$, 1,4,7-trimethyl-1,4,7-triazacyclononanone; SB, solvent-borne; TOFA, tall oil fatty acids; VOC, volatile organic compounds; $\mathrm{WB}$, water-borne.

\section{REFERENCES}

(1) Nelson, D. Alkyds and Polyesters, In Paint and Coating Testing Manual: 15th Edition of the Gardner-Sward Handbook; Koleske, J. V., Ed.; ASTM International: West Conshohocken, 2012, pp 65-71.

(2) Hofland, A. Alkyd resins: From down and out to alive and kicking. Prog. Org. Coat. 2012, 73 (4), 274-282.

(3) Lindeboom, J. Air-drying high solids alkyd pants for decorative coatings. Prog. Org. Coat. 1998, 34 (1-4), 147-151.

(4) Manea, M. High Solid Binders; Vincentz Network: Hannover, 2008.

(5) Jones, F. N. Alkyd Resins, In Ullmann's Encyclopedia of Industrial Chemistry; Wiley-VCH Verlag: Weinheim, 2003, doi:10.1002/14356007.ao1_409.

(6) McSharry, C.; Faulkner, R.; Rivers, S.; Shaffer, M. S. P.; Welton, T. The chemistry of East Asian lacquer: A review of the scientific literature. Studies in Conservation 2007, 52 (Sup. 1: Reviews in Conservation 8), 29-40.

(7) Kobayashi, S.; Uyama, H.; Ikeda, R. Artificial Urushi. Chem. Eur. J. 2001, 7 (22), 4755-476o.

(8) Gedam, P. H.; Sampathkumaran, P. S. Cashew nut shell liquid: extraction, chemistry and applications. Prog. Org. Coat. 1986, 14 (2), 115-157.

(9) Salitros, J. J. Utilization of hydroxyl terminated polybutadiene in air dry rust inhibitive primers. J. Coat. Technol. 1992, 70 (807), 47-51.

(10) Johansson, M.; Trollsas, M.; Hult, A. Synthesis, Characterization, and Curing of Well-Defined Allyl Ether-Maleate Functional Ester Oligomers: Linear versus Nonlinear Structures. J. Polym. Sci. A 1992, 30 (10), 2203-2210.

(11a) Nalawade, P. P.; Soucek, M. D. Modified soybean oil as a reactive diluent: coating performance. J. Coat. Technol. Res. 2015, 12 (6), 1005-1021.

(11b) Popadyuk, A.; Breuer, A.; Bahr, J.; Tarnavchyk, I.; Voronov, A.; Chisholm, B. J. Sucrose octaesters as reactive diluents for alkyd coatings. J. Coat. Technol. Res. 2018, 15 (3), 481-488.

(11c) Stenberg, C.; Svensson, M.; Wallström, E.; Johansson, M. Drying of linseed oil wood coatings using reactive diluents. Surf. Coat. Int. B Coat. Trans. 2005, 88 (2), 119-126.

(12) Biermann, U.; Butte, W.; Holtgrefe, R.; Feder, W.; Metzger, J. O. Esters of calendula oil and tung oil as reactive diluents for alkyd resins. Eur. J. Lipid Sci. Technol. 2010, 112 (1), 103-109.

(13) Sailer, R. A.; Soucek, M. D. Investigation of cobalt drier retardation. Eur. Polym. J. 20oo, 36 (4), 803-811.

(14) Charamzová, I.; Vinklárek, J.; Honzíček, J. Effect of primary driers on oxidative drying of high-solid alkyd binder: Investigation of thickness effects by mechanical tests and infrared spectroscopy. Prog. Org. Coat. 2018, 125, 177-185.

(15a) Leyssens, L.; Vinck, B.; Van Der Straeten, C.; Wuyts, F.; Maes, L. Cobalt toxicity in humans - A review of the potential sources and systemic health effects. Toxicology 2017, 387, 43-56.

(15b) De Boeck, M.; Kirsch-Volders, M.; Lison, D. Cobalt and antimony: genotoxicity and carcinogenicity. Mutat. Res. 2003, 533 (1-2), 135-152.
(16) Lison, D.; De Boeck, M.; Verougstraete, V.; KirschVolders, M. Update on the genotoxicity and carcinogenicity of cobalt compounds. Occup. Environ. Med. 2001, 58 (10), 619-625.

(17a) Gaschler, M. M.; Stockwell, B. R. Lipid peroxidation in cell death. Biochem. Biophys. Res. Commun. 2017, 482 (3), 419-425.

(17b) Siegel, G.; Ermilov, E.; Pries, A. R.; Winkler, K.; Schmidt, A.; Ringstad, L.; Malmsten, M.; Lindman, B. The significance of lipid peroxidation in cardiovascular disease. Colloids Surf. A 2014, 442, 173-180.

(17c) Reed, T. T. Lipid peroxidation and neurodegenerative disease. Free Radic. Biol. Med. 2011, 51 (7), 1302-1309.

(17d) Nair, U.; Bartsch, H.; Nair, J. Lipid peroxidation-induced DNA damage in cancer-prone inflammatory diseases: A review of published adduct types and levels in humans. Free Radic. Biol. Med. 2007, 43 (8), 1109-1120.

(17e) Yang, W. S.; Stockwell, B. R. Ferroptosis: Death by Lipid Peroxidation. Trends Cell Biol. 2016, 26 (3), 165-176.

(18) Bieleman, J. H. Progress in the Devolopment of Cobaltfree Drier Systems. Macromol. Symp. 2002, 187 (1), 811-821.

(19) Yin, H.; Xu, L.; Porter, N. A. Free Radical Lipid Peroxidation: Mechanisms and Analysis. Chem. Rev. 2011, 111 (10), 59445972.

(20) Porter, N. A. A Perspective on Free Radical Autoxidation: The Physical Organic Chemistry of Polyunsaturated Fatty Acid and Sterol Peroxidation. J. Org. Chem. 2013, 78 (8), 3511-3524.

(21) Pratt, D. A.; Tallman, K. A.; Porter, N. A. Free Radical Oxidation of Polyunsaturated Lipids: New Mechanistic Insights and the Development of Peroxyl Radical Clocks. Acc. Chem. Res. 2011, 44 (6), 458-467.

(22) Hage, R.; de Boer, J. W.; Maaijen, K. Manganese and Iron Catalysts in Alkyd Paints and Coatings. Inorganics 2016, 4 (2), 11.

(23) van Gorkum, R.; Bouwman, E. The oxidative drying of alkyd paint catalysed by metal complexes. Coord. Chem. Rev. 2005, 249 (17-18), 1709-1728.

(24) Soucek, M. D.; Khattab, T.; Wu, J. Review of autoxidation and driers. Prog. Org. Coat. 2012, 73 (4), 435-454.

(25a) van Zeist, W.; Bakker-Heeres, J. A. H. Evidence for Linseed Cultivation Before 6000 bc. J. Archaeol. Sci. 1975, 2 (3), 215219.

(25b) Valamoti, S. M. Flax in Neolithic and Bronze Age Greece: archaeobotanical evidence. Veget. Hist. Archaeobot. 2011, 20 (6), 549-560.

(26) Marinova, E.; Riehl, S. Carthamus species in the ancient Near East and south-eastern Europe: archaeobotanical evidence for their distribution and use as a source of oil. Veget. Hist. Archaeobot. 2009, 18 (4), 341-349.

(27a) Stefansson, B. R.; Hougen, F. W. Selection of rape plants (Brassica napus) with seed oil practically free from erucic acid. Can. J. Plant Sci. 1964, 44 (4), 359-364.

(27b) Rahman, H. Review: Breeding spring canola (Brassica napus L.) by the use of exotic germplasm. Can. J. Plant Sci. 2013, 93 (3), 363-373.

(28) Baumann, H.; Bühler, M.; Fochem, H.; Hirsinger, F.; Zoebelein, H.; Falbe, J. Natural Fats and Oils-Renewable Raw Materials for the Chemical Industry. Angew. Chem. Int. Ed. Engl. 1988, 27 (1), 41-62.

(29a) Fick, G. N. Genetics and Breeding of Sunflower. J. Am. Oil Chem. Soc. 1983, 60 (7), 1252-1253.

(29b) Gecgel, U.; Demirci, M.; Esendal, E.; Tasan, M. Fatty Acid Composition of the Oil from Developing Seeds of Different Varieties of Safflower (Carthamus tinctorius L.). J. Am. Oil Chem. Soc. 2007, 84 (1), 47-54.

(29c) Anjani, K.; Yadav, P. High yielding-high oleic non-genetically modified Indian safflower cultivars. Ind. Crops Prod. 2017, 104, 7-12. 
(30) Scarth, R.; McVetty, P. B. E.; Rimmer, S. R. Mercury high erucic low glucosinolate summer rape. Can. J. Plant Sci. 1995, 75 (1), 205-206.

(31) Canadian Grain Commission, Quality of western Canadian Canola 2018.

(32) Markman, A. L.; Andrianova, L. N.; Kruptsov, B. K.; Yusupova, I. U.; Yakushina, L. M.; Konchalovskaya, M. E. Triglycerols of oiticica oil. Chem. Nat. Compd. 1980, 16 (3), 229-232.

(33) Dulf, F. V.; Pamfil, D.; Baciu, A. D.; Pintea, A. Fatty acid composition of lipids in pot marigold (Calendula officinalis L.) seed genotypes. Chem. Cent. J. 2013, 7 (1), 8.

(34) Canadian Grain Commission, Quality of western Canadian flaxseed 2018.

(35) Dubois, V.; Breton, S.; Linder, M.; Fanni, J.; Parmentier, M. Fatty acid profiles of 80 vegetable oils with regard to their nutritional potential. Eur. J. Lipid Sci. Technol. 2007, 109 (7), 710-732.

(36) Canadian Grain Commission, Quality of Canadian oilseed-type soybeans 2018.

(37) Norlin, L. H. Tall Oil, In Ullmann's Encyclopedia of Industrial Chemistry; Wiley-VCH Verlag: Weinheim, 20oo, doi:10.1002/14356007.a26_057.

(38) Mutlu, H.; Meier, M. A. R. Castor oil as a renewable resource for the chemical industry. Eur. J. Lipid Sci. Technol. 2010, $112(1), 10-30$.

(39) de Oliveira, J. S.; Leite, P. M.; de Souza, L. B.; Mello, V. M.; Silva, E. C.; Rubim, J. C.; Meneghetti, S. M. P.; Suarez, P. A. Z. Characteristics and composition of Jatropha gossypiifolia and Jatropha curcas L. oils and application for biodiesel production. Biomass Bioenergy 2009, 33 (3), 449-453.

(40) Kleiman, R.; Smith, C. R.; Yates, S. G.; Jones, Q. Search for New Industrial Oils. XII. Fifty-eight Euphorbiaceae Oils, Including One Rich in Vernolic Acid. J. Am. Oil Chem. Soc. 1965, 42 (3), 169-172.

(41) Hettiarachchi, D.; Liu, Y.; Fox, J.; Sunderland, B. Western Australian sandalwood seed oil: new opportunities. Lipid Technol. 2010, 22 (2), 27-29.

(42) ASTM D5554-15, Standard Test Method for Determination of the Iodine Value of Fats and Oils; ASTM International: West Conshohocken, PA, 2015.

(43) Koleske, J. V. Drying Oils, In Paint and Coating Testing Manual: 15th Edition of the Gardner-Sward Handbook; Koleske, J. V., Ed.; ASTM International: West Conshohocken, 2012, pp 32-37.

(44) Carrick, L. L. Vegetable Oil Paints. J. Am. Oil Chem. Soc. 1950, 27 (11), 513.

(45) Chapman, A. C. The examination of Chinese and Japanese wood oil. Analyst 1912, 37 (441), 543-553.

(46) How, S. G. Tung Oil and tong Trees. Z. Dtsch. Morgenländ. Ges. 2017, 167 (1), 215-236.

(47a) Gardner, H. A. The Tung Oil Industry in the South. Ind. Eng. Chem. 1932, 24 (6), 687-69o.

(47b) Rinehart, T.; J., S.; Edwards, N.; Spiers, J. M.; Klasson, T. Vernicia fordii 'Spiers', a New Tung Tree for Commercial Tung Oil Production in the Gulf Coast Region. HortScience 2015, 50 (12), 1830-1832.

(47c) Brown, K.; Keeler, W. The History of Tung Oil. Wildland Weeds 2005, 9 (1), 4-6.

(48) Rawat, R.; Yu, X. H.; Sweet, M.; Shanklin, J. Conjugated fatty acid synthesis: residues 111 and 115 influence product partitioning of Momordica charantia conjugase. J. Biol. Chem. 2012, 287 (20), 16230-16237.

(49a) Cromack, H. T. H.; Smith, J. M. Calendula officinalis production potential and crop agronomy in southern England. Ind. Crops Prod. 1998, 7 (2-3), 223-229.

(49b) Króla, B.; Paszko, T. Harvest date as a factor affecting crop yield, oil content and fatty acidcomposition of the seeds of calendula (Calendula officinalis L.) cultivars. Ind. Crops Prod. 2017, 97, 242-251. (49c) Meier zu Beerentrup, H.; Röbbelen, G. Calendula and Coriandrum - New Potential Oilcrops for Industrial Uses. Eur. J. Lipid Sci. Technol. 1987, 89 (6), 227-230.

(49d) Johnson, J. M. F.; Gesch, R. W.; Barbour, N. W. Limited Seed and Seed Yield Response of Calendula to Applied Nitrogen Does Not Justify Risk of Environmental Damage from High Urea Application Rates. Agriculture 2018, 8 (3), 40.

(50) Derksen, J. T. P.; Cuperus, F. P.; Kolster, P. Renewable resources in coatings technology: a review. Prog. Org. Coat. 1996, 27 (1-4), 45-53.

(51) Teng, G.; Soucek, M. D.; Vick, B. A.; Simonsick, W. J.; Sen, A. Spectroscopic investigation of the blowing process of soyabean oil. Surf. Coat. Int. B Coat. Trans. 2003, 86 (3), 221-229.

(52) Brod, J. S.; France, W. G.; Evans, W. L. Thermal Polymerization of Ethyl Eleostearate and 9,11- and 9,12-Ethyl Linoleate. Ind. Eng. Chem. 1939, 31 (1), 114-118.

(53) Nawar, W. W. Chemical Changes in Lipids Produced by Thermal Processing. J. Chem. Educ. 1984, 61 (4), 299-302.

(54a) Figge, K. Dimeric fatty acid $\left[1^{-14} \mathrm{C}\right]$ methyl esters. I. Mechanisms and products of thermal and oxidative-thermal reactions of unsaturated fatty acid esters - literature review. Chem. Phys. Lipids 1971, 6 (2), 159-177.

(54b) Gertz, C.; Klostermann, S.; Kochhar, S. P. Testing and comparing oxidative stability of vegetable oils and fats at frying temperature. Eur. J. Lipid Sci. Technol. 20oo, 102 (8-9), 543-551.

(55) Arca, M.; Sharma, B. K.; Price, N. P. J.; Perez, J. M.; Doll, K. M. Evidence Contrary to the Accepted Diels-Alder Mechanism in the Thermal Modification of Vegetable Oil. J. Am. Oil Chem. Soc. 2012, 89 (6), 987-994.

(56) Rakoff, H.; Thomas, F. L.; Gast, L. E. Reversibility of yellowing phenomenon in linseed-based paints. J. Coat. Technol. 1979, 51 (649), 25-28.

(57) Osmond, G.; Boon, J. J.; Puskar, L.; Drennan, J. Metal stearate distributions in modern artists' oil paints: surface and cross-sectional investigation of reference paint films using conventional and synchrotron infrared microspectroscopy. Appl. Spectrosc. 2012, 66 (10), 1136-1144.

(58) Long, J. S.; Egge, W. S.; Wetterau, P. C. Action of Heat and Blowing on Linseed and Perilla Oils and Glycerides Derived from Them. Ind. Eng. Chem. 1927, 19 (8), 903-906.

(59) Thomas, A.; Matthäus, B.; Fiebig, H. Fats and Fatty Oils, In Ullmann's Encyclopedia of Industrial Chemistry; Wiley-VCH Verlag: Weinheim, 2015, doi:10.1002/14356007.a10_173.pub2.

(6o) Zanetti, F.; Monti, A.; Berti, M. T. Challenges and opportunities for new industrial oilseed crops in EU-27: A review. Ind. Crops Prod. 2013, 50, 580-595.

(61) Biermann, U.; Bornscheuer, U.; Meier, M. A. R.; Metzger, J. O.; Schäfer, H. J. Oils and Fats as Renewable Raw Materials in Chemistry. Angew. Chem. Int. Ed. 2011, 50 (17), 3854-3871.

(62) Edrisi, S. A.; Dubey, R. K.; Tripathi, V.; Bakshi, M.; Srivastava, P.; Jamil, S.; Singh, H. B.; Singh, N.; Abhilash, P. C. Jatropha curcas L.: A crucified plant waiting for resurgence. Renew. Sust. Energ. Rev. 2015, 41, 855-862.

(63) Makkar, H. P. S.; Becker, K. Jatropha curcas, a promising crop for the generation of biodiesel and value-added coproducts. Eur. J. Lipid Sci. Technol. 20o9, 111 (8), 773-787.

(64a) Odetoye, T. E.; Ogunniyi, D. S.; Olatunji, G. A. Preparation and evaluation of Jatropha curcas Linneaus seed oil alkyd resins. Ind. Crops Prod. 2010, 32 (3), 225-230.

(64b) Odetoye, T. E.; Ogunniyi, D. S.; Olatunji, G. A. Improving Jatropha curcas Linnaeus oil alkyd drying properties. Prog. Org. Coat. 2012, 73 (4), 374-381.

(65a) Chakraborty, S.; Todd, J.; Isbell, T.; Van Acker, R. C. Agronomic performance of the novel oilseed crop Euphorbia lagascae Spreng., (Euphorbiaceae) in southwestern Ontario. Ind. Crops Prod. 2018, 111, 865-870. 
(65b) Chakraborty, S.; Cici, S. Z. H.; Todd, J.; Loucks, C.; Van Acker, R. C. Exploring the weed biology of two potentially novel oilseed crops: Euphorbia lagascae and Centrapalus pauciflorus. Can. J. Plant Sci. 2016, 96 (4), 677-688.

(66) Hettiarachchi, D. S.; Liu, Y. D.; Boddy, M. R.; Fox, J. E. D.; Sunderland, V. B. Contents of Fatty Acids, Selected Lipids and Physicochemical Properties of Western Australian Sandalwood Seed Oil. J. Am. Oil Chem. Soc. 2013, 90 (2), 285-290.

(67) Carlston, E. F.; Lum, F. G. Isophthalic Acid Application in Alkyd Oils. Ind. Eng. Chem. 1957, 49 (6), 1051-1053.

(68) Niimura, N.; Miyakoshi, T.; Onodera, J.; Higuchi, T. Identification of ancient lacquer films using two-stage pyrolysisgas chromatography/mass spectrometry. Archaeometry 1999, 41 (1), 137-149.

(69) Kumanotani, J. Urushi (oriental lacquer) - a natural aesthetic durable and future-promising coating. Prog. Org. Coat. 1995, 26 (2-4), 163-195.

(7o) Igo, S.; Honda, T.; Lu, R.; Kamiya, Y.; Miyakoshi, T. Application of derivatization pyrolysis gas chromatography/mass spectrometry to analysis of archaeological lacquerwares. J. Anal. Appl. Pyrolysis 2015, 114, 302-307.

(71) Narita, C.; Yamada, K.; Tsujii, T. Solvent influence on crosslinking and surface characteristics of Urushi films. Mater. Chem. Phys. 2017, 199, 387-392.

(72) Vogl, O. Oriental Lacquer, Poison Ivy, and Drying Oils. J. Polym. Sci. A: Polym. Chem. 20oo, 38 (24), 4327-4335.

(73) Ho, A. S. L.; Regert, M.; Marescot, O.; Duhamel, C.; Langlois, J.; Miyakoshi, T.; Genty, C.; Sablier, M. Molecular criteria for discriminating museum Asian lacquerware from different vegetal origins by pyrolysis gas chromatography/mass spectrometry. Anal. Chim. Acta 2012, 710, 9-16.

(74) Bartus, J.; Simonsick, W. J.; Garner, C.; Nishiura, T.; Kitayama, T.; Hatada, K.; Vogl, O. Oriental Lacquer III. Composition of the Urushiol Fraction of the Sap of Rhus verniciflua. Polym. J. 1994, 26 (1), 67-78.

(75) Niimura, N.; Miyakoshi, T.; Onodera, J.; Higuchi, T. Structural Studies of Melanorrhoea usitate Lacquer Film Using Two-stage Pyrolysis/Gas Chromatography/Mass Spectrometry. Rapid Commun. Mass Spectrom. 1996, 10 (14), 1719-1724.

(76) Honda, T.; Lu, R.; Sakai, R.; Ishimura, T.; Miyakoshi, T. Characterization and comparison of Asian lacquer saps. Prog. Org. Coat. 2008, 61 (1), 68-75.

(77a) Tsujimoto, T.; Ikeda, R.; Uyama, H.; Kobayashi, S. Synthesis and Curing of Crosslinkable Polyphenols from Urushiol Analogues. Chem. Lett. 200o, 29 (10), 1122-1123.

(77b) Kobayashi, S.; Ikeda, R.; Oyabu, H.; Tanaka, H.; Uyama, H. Artificial Urushi: Design, Synthesis, and Enzymatic Curing of New Urushiol Analogues. Chem. Lett. 20oo, 29 (10), 1214-1215.

(77c) Ikeda, R.; Tanaka, H.; Oyabu, H.; Uyama, H.; Kobayashi, S. Preparation of Artificial Urushi via an Environmentally Benign Process. Bull. Chem. Soc. Jpn. 2001, 74 (6), 1067-1107.

(78) Tsujimoto, T.; Uyama, H.; Kobayashi, S. Synthesis and Curing Behaviors of Cross-Linkable Polynaphthols from Renewable Resources: Preparation of Artificial Urushi. Macromolecules 2004, 37 (5), 1777-1782.

(79a) Ikeda, R.; Tanaka, H.; Uyama, H.; Kobayashi, S. Enzymatic Synthesis and Curing of Poly(cardanol). Polym. J. 20oo, 32 (7), 589-593.

(79b) Ikeda, R.; Tanaka, H.; Uyama, H.; Kobayashi, S. A new crosslinkable polyphenol from a renewable resource. Macromol. Rapid Commun. 2ooo, 21 (8), 496-499.

(8oa) Otsuka, T.; Fujikawa, S.; Yamane, H.; Kobayashi, S. Green polymer chemistry: the biomimetic oxidative polymerization of cardanol for a synthetic approach to 'artificial urushi'. Polym. J. 2017, 49 (3), 335-343. (8ob) Ma, H. X.; Xu, Z. B.; Qiu, J. J.; Liu, C. M. Synthesis of artificial urushi via ring-opening reaction of benzoxazine with renewable cardanol. Polymer 2017, 132, 41-50.

(81) Ikeda, R.; Tanaka, H.; Uyama, H.; Kobayashi, S. Synthesis and curing behaviors of a crosslinkable polymer from cashew nut shell liquid. Polymer 2002, 43 (12), 3475-3481.

(82) Lubi, M. C.; Thachil, E. T. Cashew nut shell liquid (CNSL) - a versatile monomer for polymer synthesis. Designed Monomers and Polymers 200o, 3 (2), 123-153.

(83) Voirin, C.; Caillol, S.; Sadavarte, N. V.; Tawade, B. V.; Boutevin, B.; Wadgaonkar, P. P. Functionalization of cardanol: towards biobased polymers and additives. Polym. Chem. 2014, 5 (9), 3142-3162.

(84a) Ma, H. X.; Li, J. J.; Qiu, J. J.; Liu, Y.; Liu, C. M. Renewable Cardanol-Based Star-Shaped Prepolymer Containing a Phosphazene Core as a Potential Biobased Green Fire-Retardant Coating. ACS Sustainable Chem. Eng. 2017, 5 (1), 350-359.

(84b) Patel, C. J.; Mannari, V. Air-drying bio-based polyurethane dispersion from cardanol: Synthesis and characterization of coatings. Prog. Org. Coat. 2014, 77, 997-1006.

(85a) Wexler, H. Polymerization of Drying Oils. Chem. Rev. 1964, 64 (6), 591-611.

(85b) Porter, N. A.; Lehman, L. S.; Weber, B. A.; Smith, K. J. Unified Mechanism for Polyunsaturated Fatty Acid Autoxidation. Competition of Peroxy Radical Hydrogen Atom Abstraction, $\beta$ Scission, and Cyclization. J. Am. Chem. Soc. 1981, 103 (21), 64476455 .

(85c) Porter, N. A.; Wujek, D. G. Autoxidation of Polyunsaturated Fatty Acids, an Expanded Mechanistic Study. J. Am. Chem. Soc. 1984, 106 (9), 2626-2629.

(85d) Porter, N. A. Mechanisms for the Autoxidation of Polyunsaturated Lipids. Acc. Chem. Res. 1986, 19 (9), 262-268.

(86) Zielinski, Z. A. M.; Pratt, D. A. Lipid Peroxidation: Kinetics, Mechanisms, and Products. J. Org. Chem. 2017, 82 (6), 2817-2825.

(87) Ye, G.; Courtecuisse, F.; Allonas, X.; Ley, C.; CroutxeBarghorn, C.; Raja, P.; Taylor, P.; Bescond, G. Photoassisted oxypolymerization of alkyd resins: Kinetics and mechanisms. Prog. Org. Coat. 2012, 73 (4), 366-373.

(88) Brash, A. R. Lipoxygenases: Occurrence, Functions, Catalysis, and Acquisition of Substrate. J. Biol. Chem. 1999, 274, 23679-23682.

(89) Maillard, B.; Ingold, K. U.; Scaiano, J. C. Rate Constants for the Reactions of Free Radicals with Oxygen in Solution. J. Am. Chem. Soc. 1983, 105 (15), 5095-5099.

(9o) Xu, L.; Davis, T. A.; Porter, N. A. Rate Constants for Peroxidation of Polyunsaturated Fatty Acids and Sterols in Solution and in Liposomes. J. Am. Chem. Soc. 2009, 131 (36), 13037-13044.

(91) Lee, R.; Gryn'ova, G.; Ingold, K. U.; Coote, M. L. Why are sec-alkylperoxyl bimolecular self-reactions orders of magnitude faster than the analogous reactions of tert-alkylperoxyls? The unanticipated role of $\mathrm{CH}$ hydrogen bond donation. Phys. Chem. Chem. Phys. 2016, 18 (34), 23673-23679.

(92) Uhl, A.; Bitzer, M.; Wolf, H.; Hermann, D.; Gutewort, S.; Völkl, M.; Nagl, I. Peroxy Compounds, Organic., In Ullmann's Encyclopedia of Industrial Chemistry; Wiley-VCH Verlag: Weinheim, 2018, doi:10.1002/14356007.a19_199.pub2.

(93) Wilson, Z. R.; Siebert, M. R. Methyl Linoleate and Methyl Oleate Bond Dissociation Energies: Electronic Structure Fishing for Wise Crack Products. Energy Fuels 2018, 32 (2), 1779-1787.

(94) Howard, J. A.; Ingold, K. U. Absolute rate constants for hydrocarbon autoxidation. VI. Alkyl aromatic and olefinic hydrocarbons. Can. J. Chem. 1966, 45 (8), 793-802.

(95) Tallman, K. A.; Rector, C. L.; Porter, N. A. Substituent Effects on Regioselectivity in the Autoxidation of Nonconjugated Dienes. J. Am. Chem. Soc. 2009, 131 (15), 5635-5641. 
(96) Porter, N. A.; Mills, K. A.; Carter, R. L. A Mechanistic Study of Oleate Autoxidation: Competing Peroxyl H-Atom Abstraction and Rearrangement. J. Am. Chem. Soc. 1994, 116 (15), 669o-6696.

(97) Tallman, K. A.; Pratt, D. A.; Porter, N. A. Kinetic Products of Linoleate Peroxidation: Rapid $\beta$-Fragmentation of Nonconjugated Peroxyls. J. Am. Chem. Soc. 2001, 123 (47), 11827-11828.

(98) Tallman, K. A.; Roschek, B.; Porter, N. A. Factors Influencing the Autoxidation of Fatty Acids: Effect of Olefin Geometry of the Nonconjugated Diene. J. Am. Chem. Soc. 2004, 126 (30), 9240-9247.

(99) Coxon, D. T.; Price, K. R.; Chan, H. W. S. Formation, isolation and structure determination of methyl linolenate diperoxides. Chem. Phys. Lipids 1981, 28 (4), 365-378.

(10o) Chan, H. W. S.; Matthew, J. A.; Coxon, D. T. A hydroperoxy-epidioxide from the autoxidation of a hydroperoxide of methyl linolenate. J. Chem. Soc., Chem. Commun. 1980 (5), 235-236.

(101) Yurawecz, M. P.; Hood, J. K.; Mossoba, M. M.; Roach, J. A. G.; Ku, Y. Furan Fatty Acids Determined as Oxidation Products of Conjugated Octadecadienoic Acid. Lipids 1995, 30 (7), 595-598; Privett, O. S. Autoxidation and Autoxidative Polymerization. J. Am. Oil Chem. Soc. 1959, 36 (10), 507-510.

(102a) Hämäläinen, T. I.; Sundberg, S.; Mäkinen, M.; Kaltia, S.; Hasea, T.; Hopia, A. Hydroperoxide formation during autoxidation of conjugated linoleic acid methyl ester. Eur. J. Lipid Sci. Technol. 2001, 103 (9), 588-593.

(102b) Pajunen, T. I.; Johansson, M. P.; Hase, T.; Hopia, A. Autoxidation of Conjugated Linoleic Acid Methyl Ester in the Presence of $\alpha$-Tocopherol: The Hydroperoxide Pathway. Lipids 2oo8, 43 (7), 599-610.

(102c) Pajunen, T. I.; Koskela, H.; Hase, T.; Hopia, A. NMR properties of conjugated linoleic acid (CLA) methyl ester hydroperoxides. Chem. Phys. Lipids 2008, 154 (2), 105-114.

(103) Hämäläinen, T. I.; Sundberg, S.; Hase, T.; Hopia, A. Stereochemistry of the Hydroperoxides Formed During Autoxidation of CLA Methyl Ester in the Presence of $\alpha$-Tocopherol. Lipids 2002, 37 (6), 533-540.

(104) Stratton, S. P.; Liebler, D. C. Determination of Singlet Oxygen-Specific versus Radical-Mediated Lipid Peroxidation in Photosensitized Oxidation of Lipid Bilayers: Effect of $\beta$-Carotene and $\alpha$-Tocopherol. Biochemistry 1997, 36 (42), 12911-12920.

(105) Greer, A. Christopher Foote's Discovery of the Role of Singlet Oxygen $\left[{ }^{1} \mathrm{O}_{2}\left({ }^{1} \Delta_{\mathrm{g}}\right)\right]$ in Photosensitized Oxidation Reactions. Acc. Chem. Res. 2006, 39 (11), 797-804.

(106a) Pryor, W. A.; Houk, K. N.; Foote, C. S.; Fukuto, J. M.; Ignarro, L. J.; Squadrito, G. L.; Davies, K. J. Free radical biology and medicine: it's a gas, man! Am. J. Physiol. Regul. Integr. Comp. Physiol. 2006, 291 (3), R491-R511.

(106b) Bisby, R. H.; Morgan, C. G.; Hamblett, I.; Gorman, A. A. Quenching of Singlet Oxygen by Trolox C, Ascorbate, and Amino Acids: Effects of $\mathrm{pH}$ and Temperature. J. Phys. Chem. A 1999, 103 (37), 7454-7459.

(106c) Chacón, J. N.; Gaggini, P.; Sinclair, R. S.; Smith, F. J. Photo- and thermal-oxidation studies on methyl and phenyl linoleate: anti-oxidant behaviour and rates of reaction. Chem. Phys. Lipids 2000, 107 (1), 107-120.

(107) Hubert, J. C.; Venderbosch, R. A. M.; Muizebelt, W. J.; Klaasen, R. P.; Zabel, K. H. Singlet Oxygen Drying of Alkyd Resins and Model Compounds. J. Coat. Technol. 1997, 69 (869), 59-64.

(108) Frimer, A. A. The Reaction of Singlet Oxygen with Olefins: The Question of Mechanism. Chem. Rev. 1979, 79 (5), 359387.

(109) Spier, E.; Neuenschwander, U.; Hermans, I. Insights into the Cobalt(II)-Catalyzed Decomposition of Peroxide. Angew. Chem. Int. Ed. 2013, 52 (5), 1581-1585.

(110) Oyman, Z. O.; Ming, W.; van der Linde, R.; van Gorkum, R.; Bouwman, E. Effect of $\left[\mathrm{Mn}(\mathrm{acac})_{3}\right]$ and its combination with 2,2'-bipyridine on the autoxidation and oligomerisation of ethyl linoleate. Polymer 2005, 46 (6), 1731-1738.

(111) van Gorkum, R.; Bouwman, E.; Reedijk, J. Fast Autoxidation of Ethyl Linoleate Catalyzed by $\left[\mathrm{Mn}(\mathrm{acac})_{3}\right]$ and Bipyridine: A Possible Drying Catalyst for Alkyd Paints. Inorg. Chem. 2004, 43 (8), 2456-2458.

(112) Micciche, F.; Long, G. J.; Shahin, A. M.; Grandjean, F.; Ming, W.; van Haveren, J.; van der Linde, R. The combination of ascorbic acid 6-palmitate and $\left[\mathrm{Fe}_{3}^{\mathrm{III}}\left(\mu_{3}-\mathrm{O}\right)\right]^{7+}$ as a catalyst for the oxidation of unsaturated lipids. Inorg. Chim. Acta 2007, 360 (2), 535-545.

(113) Micciche, F.; van Straten, M. A.; Ming, W.; Oostveen, E.; van Haveren, J.; van der Linde, R.; Reedijk, J. Identification of mixed-valence metal clusters in drier solutions for alkyd-based paints by electrospray ionization mass spectrometry (ESI-MS). Int. J. Mass Spectrom. 2005, 246 (1-3), 80-83.

(114) Tanase, S.; Bouwman, E.; Reedijk, J. Role of additives in cobalt-mediated oxidative crosslinking of alkyd resins. Appl. Catal. A 2004, 259 (1), 101-104.

(115) Spier, E.; Hermans, I. Enhancing the deperoxidation activity of cobalt(II)acetylacetonate by the addition of octanoic acid. ChemPhysChem 2013, 14 (14), 3384-3388.

(116) Turra, N.; Neuenschwander, U.; Baiker, A.; Peeters, J.; Hermans, I. Mechanism of the Catalytic Deperoxidation of tertButylhydroperoxide with Cobalt(II) Acetylacetonate. Chem. Eur. J. 2010, 16 (44), 13226-13235.

(117) Chavez, F. A.; Mascharak, P. K. Co(III)-Alkylperoxo Complexes: Syntheses, Structure-Reactivity Correlations, and Use in the Oxidation of Hydrocarbons. Acc. Chem. Res. 20oo, 33 (8), 539-545.

(118) Chaves, F. A.; Briones, J. A.; Olmstead, M. M.; Mascharak, P. K. Syntheses and Stuctures of Alkyl Peroxo Adducts of $\beta$-Diketonate Cobalt(III) Complexes and Their Role in Oxidation of Hydrocarbons and Olefin Epoxidation. Inorg. Chem. 1999, 38 (7), 1603-1608.

(119) Roy, S.; Roy, S.; Saha, S.; Majumdar, R.; Dighe, R. R.; Jemmis, E. D.; Chakravarty, A. R. Cobalt(II) complexes of terpyridine bases as photochemotherapeutic agents showing cellular uptake and photocytotoxicity in visible light. Dalton Trans. 2011, 40 (6), 1233-1242.

(120) Burg, A.; Shusterman, I.; Kornweitz, H.; Meyerstein, D. Three $\mathrm{H}_{2} \mathrm{O}_{2}$ molecules are involved in the "Fenton-like" reaction between $\mathrm{Co}\left(\mathrm{H}_{2} \mathrm{O}\right)_{6}{ }^{2+}$ and $\mathrm{H}_{2} \mathrm{O}_{2}$. Dalton Trans. 2014, 43 (24), 91119115.

(121) Oyman, Z. O.; Ming, W.; van der Linde, R. Oxidation of model compound emulsions for alkyd paints under the influence of cobalt drier. Prog. Org. Coat. 2003, 48 (1), 80-91.

(122) Nackerdien, Z.; Kasprzak, K. S.; Rao, G.; Halliwell, B.; Dizdaroglu, M. Nickel(II)- and cobalt(II)-dependent damage by hydrogen peroxide to the DNA bases in isolated human chromatin. Cancer Res. 1991, 51 (21), 5837-5842.

(123) Erich, S. J. F.; Gezici-Koç, Ö.; Michel, M. E. B.; Thomas, C. A. A. M.; van der Ven, L. G. J.; Huinink, H. P.; Flapper, J.; Duivenvoorde, F. L.; Adan, O. C. G. The influence of calcium and zirconium based secondary driers on drying solvent borne alkyd coatings. Polymer 2017, 121, 262-273.

(124) Bouwman, E.; van Gorkum, R. A study of new manganese complexes as potential driers for alkyd paints. J. Coat. Technol. Res. 2007, 4 (4), 491-503.

(125a) Wu, J. Z.; Bouwman, E.; Reedijk, J. Chelating ligands as powerful additives to manganese driers for solvent-borne and water-borne alkyd paints. Prog. Org. Coat. 2004, 49 (2), 103-108.

(125b) Lima, G. E. S.; Nunes, E. V.; Dantas, R. C.; Meneghetti, M. R.; Meneghetti, S. M. P. Systematic investigation of the oxidative polymerization of linseed oil catalyzed by $\mathrm{Co}(\mathrm{II}), \mathrm{Mn}(\mathrm{II})$, and Fe(II) complexes with chelating nitrogen ligands. Eur. J. Lipid Sci. Technol. 2015, 117 (2), 229-234. 
(152c) Lima, G. E. S.; Nunes, E. V.; Dantas, R. C.; de Simone, C. A.; Meneghetti, M. R.; Meneghetti, S. M. P. Catalytic Behaviors of $\mathrm{Co}^{\mathrm{II}}$ and $\mathrm{Mn}^{\mathrm{II}}$ Compounds Bearing $\beta$-Diimine Ligands for Oxidative Polymerization or Drying Oils. J. Braz. Chem. Soc. 2018, 29 (2), 412-418.

(126) Warzeska, S. T.; Zonneveld, M.; van Gorkum, R.; Muizebelt, W. J.; Bouwman, E.; Reedijk, J. The influence of bipyridine on the drying of alkyd paints: a model study. Prog. Org. Coat. 2002, 44 (3), 243-248.

(127a) van Gorkum, R.; Berding, J.; Tooke, D. M.; Spek, A. L.; Reedijk, J.; Bouwman, E. The autoxidation activity of new mixedligand manganese and iron complexes with tripodal ligands. $J$. Catal. 2007, 252 (1), 110-118.

(127b) van Gorkum, R.; Berding, J.; Mills, A. M.; Kooijman, H.; Tooke, D. M.; Spek, A. L.; Mutikainen, I.; Turpeinen, U.; Reedijk, J.; Bouwman, E. The Synthesis, Structures and Characterisation of New Mixed-Ligand Manganese and Iron Complexes with Tripodal, Tetradentate Ligands. Eur. J. Inorg. Chem. 2008 (9), 14871496.

(128) Hage, R.; Iburg, J. E.; Kerschner, J.; Koek, J. H.; Lempers, E. L. M.; Martens, R. J.; Racherla, U. S.; Russell, S. W.; Swarthoff, T.; van Vliet, M. R. P.; Warnaar, J. B.; van der Wolf, L.; Krijnen, B. Efficient manganese catalysts for low-temperature bleaching. $\mathrm{Na}$ ture 1994, 369, 637-639.

(129a) Liu, Z.; Kooijman, H.; Spek, A. L.; Bouwman, E. New manganese-based catalyst systems for alkyd paint drying. Prog. Org. Coat. 2007, 6o (4), 343-349.

(129b) Oyman, Z. O.; Ming, W.; van der Linde, R. Oxidation of ${ }^{13} \mathrm{C}$-labeled ethyl linoleate monitored and quantitatively analyzed by ${ }^{13}$ C NMR. Eur. Polym. J. 2006, 42 (6), 1342-1348.

(130) van Gorkum, R.; Buda, F.; Kooijman, H.; Spek, A. L.; Bouwman, E.; Reedijk, J. Trigonal-Prismatic vs. Octahedral Geometry for $\mathrm{Mn}^{\mathrm{II}}$ Complexes with Innocent Didentate Ligands: A Subtle Difference as Shown by XRD and DFT on [Mn(acac $\left.)_{2}(\mathrm{bpy})\right]$. Eur. J. Inorg. Chem. 2005 (11), 2255-2261.

(131) Hage, R.; Lienke, A. Applications of Transition-Metal Catalysts to Textile and Wood-Pulp Bleaching. Angew. Chem. Int. Ed. 2006, 45 (2), 206-222.

(132) Oyman, Z. O.; Ming, W.; Micciche, F.; Oostveen, E.; van Haveren, J.; van der Linde, R. A promising environmentallyfriendly manganese-based catalyst for alkyd emulsion coatings. Polymer 2004, 45 (22), 7431-7436.

(133) Oyman, Z. O.; Ming, W.; van der Linde, R. Catalytic activity of a dinuclear manganese complex (MnMeTACN) on the oxidation of ethyl linoleate. Appl. Catal. A 2007, 316 (2), 191-196.

(134) Hage, R.; Krijnen, B.; Warnaar, J. B.; Hartl, F.; Stufkens, D. J.; Snoeck, T. L. Proton-Coupled Electron-Transfer Reactions in $\left[\mathrm{Mn}_{2}{ }_{2}(\mu-\mathrm{O})_{3} \mathrm{~L}_{2}\right]^{2+}\left(\mathrm{L}^{\prime}=1,4,7\right.$-Trimethyl-1,4,7-triazacyclononane $)$ Inorg. Chem. 1995, 34 (20), 4973-4978.

(135) Oyman, Z. O.; Ming, W.; van der Linde, R.; ter Borg, J.; Schut, A.; Bieleman, J. H. Oxidative drying of alkyd paints catalysed by a dinuclear manganese complex (MnMeTACN). Surf. Coat. Int. B Coat. Trans. 2005, 88 (4), 269-275.

(136) Gezici-Koç, Ö.; Thomas, C. A. A. M.; Michel, M. E. B.; Erich, S. J. F.; Huinink, H. P.; Flapper, J.; Duivenvoorde, F. L.; van der Ven, L. G. J.; Adan, O. C. G. In-depth study of drying solventborne alkyd coatings in presence of $\mathrm{Mn}$ - and Fe- based catalysts as cobalt alternatives. Mater. Today Commun. 2016, 7, 22-31.

(137) Micciche, F.; Oostveen, E.; van Haveren, J.; van der Linde, R. The combination of reducing agents/iron as environmentally friendlier alternatives for Co-based driers in the drying of alkyd paints. Prog. Org. Coat. 2005, 53 (2), 99-105.

(138a) Micciche, F.; van Haveren, J.; Oostveen, E.; Ming, W.; van der Linde, R. Oxidation and oligomerization of ethyl linoleate under the influence of the combination of ascorbic acid 6-palmitate/iron-2-ethylhexanoate. Appl. Catal. A 2006, 297 (2), 174-181. (138b) van Haveren, J.; Oostveen, E. A.; Micciché, F.; Noordover, B. A. J.; Koning, C. E.; van Benthem, R. A. T. M.; Frissen, A. E.; Weijnen, J. G. J. Resins and additives for powder coatings and alkyd paints, based on renewable resources. J. Coat. Technol. Res. 2007, 4 (2), 177-186.

(139) de Boer, J. W.; Wesenhagen, P. V.; Wenker, E. C. M.; Maaijen, K.; Gol, F.; Gibbs, H.; Hage, R. The Quest for Cobalt-Free Alkyd Paint Driers. Eur. J. Inorg. Chem. 2013 (21), 3581-3591.

(140a) Pirš, B.; Znoj, B.; Skale, S.; Zabret, J.; Godnjavec, J.; Venturini, P. Iron as an alternative drier for curing of high-solid alkyd coatings. J. Coat. Technol. Res. 2015, 12 (6), 965-974.

(140b) Pirš, B.; Znoj, B.; Skale, S.; Zabret, J.; Godnjavec, J.; Berce, P.; Venturini, P. The Influence Of $\mathrm{Co} / \mathrm{Sr}$ and $\mathrm{Fe} / \mathrm{Sr}$ Driers on Film Formation of High Solid Alkyd Coatings. Acta Chim. Slov. 2015, 62 (1), 52-59.

(141) Křižan, M.; Vinklárek, J.; Erben, M.; Císařová, I.; Honzíček, J. Autoxidation of alkyd resins catalyzed by iron(II) bispidine complex: Drying performance and in-depth infrared study. Prog. Org. Coat. 2017, 111, 361-370.

(142) Křižan, M.; Vinklárek, J.; Erben, M.; Růžičková, Z.; Honzíček, J. Iron(II) complex with modified bispidine ligand: Synthesis and catalytic alkyd drying. Inorg. Chim. Acta 2019, 486, 636641.

(143) Comba, P.; Lee, Y. M.; Nam, W.; Waleska, A. Catalytic oxidation of alkanes by iron bispidine complexes and dioxygen: oxygen activation versus autoxidation. Chem. Commun. 2014, 50 (4), 412-414.

(144) Börzel, H.; Comba, P.; Hagen, K. S.; Lampeka, Y. D.; Lienke, A.; Linti, G.; Merz, M.; Pritzkow, H.; Tsymbal, L. V. Iron coordination chemistry with tetra-, penta- and hexadentate bispidine-type ligands. Inorg. Chim. Acta 2002, 337, 407-419.

(145) Kalenda, P.; Holeček, J.; Veselý, D.; Erben, M. Influence of methyl groups on ferrocene on rate of drying of oxidizable paints by using model compounds. Prog. Org. Coat. 2006, 56 (23), 111-113.

(146) Erben, M.; Veselý, D.; Vinklárek, J.; Honzíček, J. Acylsubstituted ferrocenes as driers for solvent-borne alkyd paints. $J$. Mol. Catal. A: Chem. 2012, 353-354, 13-21.

(147) Stava, V.; Erben, M.; Vesely, D.; Kalenda, P. Properties of metallocene complexes during the oxidative crosslinking of air drying coatings. J. Phys. Chem. Solids 2007, 68 (5-6), 799-802.

(148) Honzíček, J.; Vinklárek, J. Chemical curing of alkyd resin catalyzed by benzoylferrocene: Performance, kinetics, and thickness effects. J. Appl. Polym. Sci. 2018, 135 (16), 46184.

(149a) Jaroušek, J.; Šlosar, P. Suitability of a hexaisoindoline ferrum complex as a siccative. Sb. Ved. Praci, Vys. Skola Chem. Technol., Pardubice 1986, 49b, 381-39o.

(149b) Kaufmann, H. P.; Fleiter, L. Pro- and Antioxidants in the Field of Fats XII: Heavy Metal-Complex-Compounds as Prooxidants, 3. Contribution: Iron Complex Salt of a Hydroxylated Cyclic Polyisoindoline. Fette, Seifen, Anstrichm. 1964, 66 (10), 819-824.

(150) Kieler, H. M.; Bierman, M. J.; Guzei, I. A.; Liska, P. J.; McGaff, R. W. Racemic iron(III) and cobalt(III) complexes containing a new pentadentate "helmet" phthalocyaninato ligand. Chem. Commun. 2006 (31), 3326-3328.

(151) Dubrulle, L.; Lebeuf, R.; Nardello-Rataj, V. Oxidative drying properties of a helmet pentadentate phthalocyanine derived iron(III) complex. Prog. Org. Coat. 2019, 131, 364-370.

(152) Preininger, O.; Vinklárek, J.; Honzíček, J.; Mikysek, T.; Erben, M. A promising drying activity of environmentally friendly oxovanadium(IV) complexes in air-drying paints. Prog. Org. Coat. 2015, 88, 191-198.

(153a) Preininger, O.; Charamzová, I.; Vinklárek, J.; Císařová, I.; Honzíček, J. Oxovanadium(IV) complexes bearing substituted pentane-2,4-dionate ligands: Synthesis, structure and drying activity in solvent-borne alkyd paints. Inorg. Chim. Acta 2017, 462, 16-22. 
(153b) Charamzová, I.; Machálková, A.; Vinklárek, J.; Císařová, I.; Honzíček, J. Benzyl substituted oxidovanadium(IV) pentane2,4-dionates: Synthesis, structure and drying properties. Inorg. Chim. Acta 2019, 492, 243-248.

(154) Preininger, O.; Honzíček, J.; Kalenda, P.; Vinklárek, J. Drying activity of oxovanadium(IV) 2-ethylhexanoate in solventborne alkyd paints. J. Coat. Technol. Res. 2016, 13 (3), 479-487.

(155) Charamzová, I.; Vinklárek, J.; Kalenda, P.; Honzíček, J. Application of Oxovanadium Complex Stabilized by $\mathrm{N}, \mathrm{N}, \mathrm{N}, \mathrm{N}-$ Chelating Ligand in Air-Drying Paints. Coatings 2018, 8 (6), 204.

(156) Honzíček, J.; Kalenda, P.; Veselý, D.; Vinklárek, J.; Charamzová, I. Paints containing driers based on vanadium compounds and application of these compounds as driers in paints, CZ307597B6, 2019.

(157) Oakley, L. H.; Casadio, F.; Shull, K. R.; Broadbelt, L. J. Examination of Mechanisms for Formation of Volatile Aldehydes from Oxidation of Oil-Based Systems. Ind. Eng. Chem. Res. 2018, 57 (1), 139-149.

(158a) Villaverde, J. J.; Santos, S. A.; Maciel, E.; Simőes, M. M.; Neto, C. P.; Domingues, M. R.; Silvestre, A. J. Formation of oligomeric alkenylperoxides during the oxidation of unsaturated fatty acids: an electrospray ionization tandem mass spectrometry study. J. Mass Spectrom. 2012, 47 (2), 163-172.

(158b) Muizebelt, W. J.; Hubert, J. C.; Venderbosch, R. A. M. Mechanistic study of drying of alkyd resins using ethyl linoleate as a model substance. Prog. Org. Coat. 1994, 24 (1-4), 263-279.

(159) Marton, B.; van der Ven, L. G. J.; Otto, C.; Uzunbajakava, N.; Vancso, J. V. A depth-resolved look at the network development in alkyd coatings by confocal Raman microspectroscopy. Polymer 2005, 46 (25), 11330-11339.

(160a) Mallégol, J.; Lemaire, J.; Gardette, J. L. Yellowing of OilBased Paints. Studies in Conservation 2oo1, 46 (2), 121-131.

(16ob) O'Neill, L. A. Application of infrared spectroscopy for the examination of the drying yellow discoloration of oil films. Paint Technol. 1963, 27 (1), 44-47.

(161) Russell, G. A. Deuterium-isotope Effects in the Autoxidation of Aralkyl Hydrocarbons. Mechanism of the Interaction of Peroxy Radicals. J. Am. Chem. Soc. 1957, 79 (14), 3871-3877.

(162) Frenette, M.; Scaiano, J. C. Evidence for Hydroxyl Radical Generation During Lipid (Linoleate) Peroxidation. J. Am. Chem. Soc. 2008, 130 (30), 9634-9635.

(163) Erich, S. J. F.; Adan, O. C. G.; Pel, L.; Huinink, H. P.; Kopinga, K. NMR Imaging of Coatings on Porous Substrates. Chem. Mater. 2006, 18 (18), 4500-4504.

(164) Sturdy, L. F.; Yee, A.; Casadio, F.; Shull, K. R. Quantitative characterization of alkyd cure kinetics with the quartz crystal microbalance. Polymer 2016, 103, 387-396.

(165) Smith, L. M.; Aitken, H. M.; Coote, M. L. The Fate of the Peroxyl Radical in Autoxidation: How Does Polymer Degradation Really Occur? Acc. Chem. Res. 2018, 51 (9), 2006-2013.

(166) Oakley, L. H.; Casadio, F.; Shull, K. R.; Broadbelt, L. J. Microkinetic modeling of the autoxidative curing of an alkyd and oil-based paint model system. Appl. Phys. A 2015, 121 (3), 869-878.

(167) Oakley, L. H.; Casadio, F.; Shull, K. R.; Broadbelt, L. J. Modeling the Evolution of Crosslinked and Extractable Material in an Oil-Based Paint Model System. Angew. Chem. Int. Ed. 2018, 57 (25), 7413-7417.

(168) Bieleman, J.; Bolle, T.; Braig, A.; Glaser, J. K.; Spang, R.; Köhler, M.; Valet, A. Additives for Special Functions, In Additives for Coatings; Bieleman, J., Ed.; Wiley-VCH Verlag: Weinheim, 2000, pp 257-352.

(169) Ingold, K. U.; Pratt, D. A. Advances in Radical-Trapping Antioxidant Chemistry in the 21st Century: A Kinetics and Mechanisms Perspective. Chem. Rev. 2014, 114 (18), 9022-9046.

(170) Poon, J. F.; Pratt, D. A. Recent Insights on Hydrogen Atom Transfer in the Inhibition of Hydrocarbon Autoxidation. Acc. Chem. Res. 2018, 51 (9), 1996-2005.
(171) Tanase, S.; Hierso, J. C.; Bouwman, E.; Reedijk, J.; ter Borg, J.; Bieleman, J. H.; Schut, A. New insights on the anti-skinning effect of methyl ethyl ketoxime in alkyd paints. New J. Chem. 2003, 27 (5), 854-859.

(172) Shaffer, D.; Heicklen, J. Oxidation of Diethylhydroxylamine in Water Solution at $25-80{ }^{\circ} \mathrm{C}$. J. Phys. Chem. 1986, go (18), 4408-4413.

(173a) Derelanko, M. J.; Rinehart, W. E.; Rodwell, D. E. Developmental toxicity studies of methyl ethyl ketoxime (MEKO) in rats and rabbits. Drug Chem. Toxicol. 2003, 26 (3), 147-168.

(173b) Newton, P. E.; Wooding, W. L.; Bolte, H. F.; Derelanko, M. J.; Hardisty, J. F.; Rinehart, W. E. A chronic inhalation toxicity/oncogenicity study of methylethylketoxime in rats and mice. Inhal. Toxicol. 2001, 13 (12), 1093-1116.

(173c) Newton, P. E.; Bolte, H. F.; Derelanko, M. J.; Hardisty, J. F.; Rinehart, W. E. An evaluation of changes and recovery in the olfactory epithelium in mice after inhalation exposure to methylethylketoxime. Inhal. Toxicol. 2002, 14 (12), 1249-126o.

(174) Steinert, A. Anti-skinning agents having a mixture of organic compounds and coating compositions containing them, US2007/0022906A1, 2007.

(175a) Weil, J. T.; Windle, J. J. Electron spin resonance study of nitroxide radicals from diethylhydroxylamine, dioctylhydroxylamine and $N$-hydroxypyrrolidine. Nature 1968, 217 (5131), 842-843.

(175b) Astolfi, P.; Greci, L.; Paul, T.; Ingold, K. U. Revision of the $\alpha^{\mathrm{H}}{ }_{2}$ value for $N, N$-dialkylhydroxylamines based on kinetic and spectroscopic measurements. J. Chem. Soc., Perkin Trans. 22001 (9), 1631-1633.

(176a) Bieleman, J.; Lomölder, R. Catalytically Active Additives, In Additives for Coatings; Bieleman, J., Ed.; Wiley-VCH Verlag: Weinheim, 2000, pp 201-256.

(176b) Bieleman, J. H. Driers. Chimia 20o2, 56 (5), 184-19o.

(177a) Mallégol, J.; Barry, A. M.; Ciampi, E.; Glover, P. M.; McDonald, P. J.; Keddie, J. L.; Wallin, M.; Motiejauskaite, A.; Weissenborn, P. K. Influence of Drier Combination on ThroughDrying in Waterborne Alkyd Emulsion Coatings Observed with Magnetic Resonance Profiling. J. Coat. Technol. 2002, 74 (933), 113124 .

(177b) Mallégol, J.; Lemaire, J.; Gardette, J. L. Drier influence on the curing of linseed oil. Prog. Org. Coat. 200o, 39 (2-4), 107113.

(178) Lucarini, M.; Mugnaini, V.; Pedulli, G. F. Bond Dissociation Enthalpies of Polyphenols: The Importance of Cooperative Effects. J. Org. Chem. 2002, 67 (3), 928-931.

(179) Watanabe, H.; Fujimoto, A.; Takahara, A. Characterization of Catechol-Containing Natural Thermosetting Polymer "Urushiol" Thin Film. J. Polym. Sci. A: Polym. Chem. 2ooo, 51 (17), 3688-3692.

(180) Oshima, R.; Yamauchi, Y.; Watanabe, C.; Kumanotani, J. Enzymic Oxidative Coupling of Urushiol in Sap of the Lac Tree, Rhus vernicifera. J. Org. Chem. 1985, 50 (15), 2613-2621.

(181) Lu, R.; Harigaya, S.; Ishimura, T.; Nagase, K.; Miyakoshi, $\mathrm{T}$. Development of a fast drying lacquer based on raw lacquer sap. Prog. Org. Coat. 2004, 51 (3), 238-243.

(182) Lu, R.; Kanamori, D.; Miyakoshi, T. Characterization of Thitsiol Dimer Structures from Melanorrhoea usitata with Laccase Catalyst by NMR Spectroscopy. Int. J. Polym. Anal. Ch. 2011, 16 (2), 86-94.

(183) Ikeda, R.; Tsujimoto, T.; Tanaka, H.; Oyabu, H.; Uyama, H.; Kobayashi, S. Man-made urushi: Preparation of crosslinked polymeric films from renewable resources via air-oxidation processes. Proc. Jpn. Acad., Ser. B 200o, 76 (10), 155-16o.

(184) Watanabe, H.; Fujimoto, A.; Nishida, J.; Ohishi, T.; Takahara, A. Biobased Polymer Coating Using Catechol Derivative Urushiol. Langmuir 2016, 32 (18), 4619-4623. 
(185) Goldberg, M.; Farver, O.; Pecht, I. Interaction of Rhus Laccase with Dioxygen and Its Reduction Intermediates. J. Biol. Chem. 1980, 255 (15), 7353-7361.

(186) Terada, M.; Oyabu, H.; Aso, Y. Hardening Reaction of Alkenylcatechol Derivatives by Laccase from Pycnoporus Coccineus. J. Jpn. Soc. Colour Mater. 1994, 67 (11), 681-687.
(187) Ikeda, R.; Tanaka, H.; Uyama, H.; Kobayashi, S. Oxidative Polymerization of 2,6-Difluorophenol to Crystalline Poly(2,6difluoro-1,4-phenylene oxide). Macromolecules 20oo, 33 (18), $6648-6652$. 
This review article provides a comprehensive overview of curing processes relevant to air-drying paints.

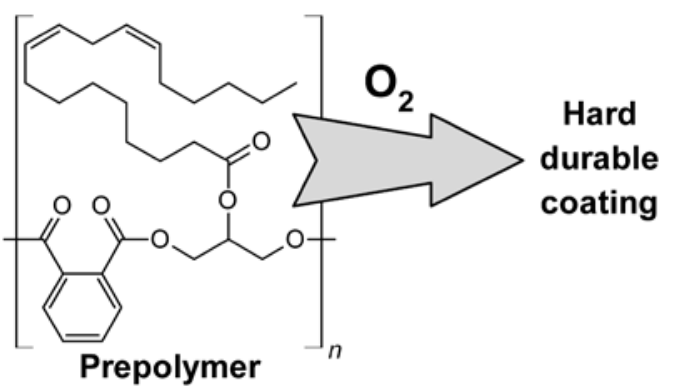

